\title{
阿武隈地域の温泉水の地球化学的研究
}

\author{
高橋 正明"1。風早 康平*1。安原 正也"1 。 \\ 高橋 浩*1・森川 德敏"1・稲村 明彦*1
}

\section{Geochemical study of hot spring waters in Abukuma area, northeast Japan}

\author{
Masaaki TAKAHASHI ${ }^{* 1}$, Kohei KAZAHAYA ${ }^{* 1}$, Masaya YASUHARA*1, \\ Hiroshi A. TAKAHASHI ${ }^{* 1}$, Noritoshi MORIKAWA*1 and Akihiko INAMURA*1
}

\begin{abstract}
Analyses of chemical compositions and hydrogen and oxygen isotopic ratios were carried out for 167 hot and cold spring waters from Abukuma area, northeasten part of Ibaraki, eastern part of Fukushima and southeastern part of Miyagi Prefectures, northeast Japan.

As a result, followings were concluded.

(1) Heat sources of all hot springs were able to be explained by conductive heat flow in this area, except those in the western side of the Abukuma River, near the volcanic front of northeast Japan.

(2) Vertical variation of geochemical characteristics of hot spring waters in this area was $\mathrm{Cl}$ type at the lowermost part, followed by $\mathrm{Cl}_{-} \mathrm{SO}_{4}$ and $\mathrm{Cl}-\mathrm{HCO}_{3}$ types at the lower part, $\mathrm{Cl} / \mathrm{SO}_{4} / \mathrm{HCO}_{3}$ types at the upper part, and $\mathrm{SO}_{4}$ type and $\mathrm{SO}_{4} / \mathrm{HCO}_{3}$ types at the uppermost part.

(3) Hot spring waters in this area were categorized into two types by their origins. The first type of hot spring waters were originated from interstitial water or oil field brine which had very high chloride ion concentration and very low sulfate ion concentration. The second type of hot spring waters were originated from meteoric water. Chloride and sulfate ions in them were leached out from minerals in layers which had both high chloride and sulfate ion concentration, although chloride ion in them had a possibility for the origin from brine in layers.
\end{abstract}

Key words: Abukuma, isotopic ratio, greentuff type hot spring, oil field brine, interstitial water キーワード：阿武隈, 同位体組成, グリーンタフ型温泉, 油田鹹水, 間隙水

\section{I ．はじめに}

阿武隈地域は東北日本弧火山フロントの東側 （前面）に位置する。そのためそこに存在する温 泉は火山（活動）の熱的, 物質的影響を受けてい る可能性が低いことが考えられる。阿武德地域は
主に海成の第三紀層および花崗岩類より構成され ているので, 本地域の温泉水の化学組成の詳細, 起源, 形成機構を調查・研究することは, 地質的 に同様の地層, 岩石から構成され, 火山（活動） の熱的, 物質的影響を受けている地域にある温泉 の起源, 形成機構を解明する上で, バックグラウ

* 1 産業技術総合研究所深部地質環境研究センター Research Center for Deep Geological Environments, National Institute of Advanced Industrial Science and Technology 
ンドとなる可能性を持つと考えられる。しかしな がら現状では阿武隈地域の温泉は化学組成の報告 （例えば，福島県厚生部，1978）以外はほとんど 行われておらず, 地球化学的な温泉調査・研究の 空白地带であるということができる。

一方で，阿武隈地域南東部にある常磐湯本温泉 は, 東北日本弧の火山フロントより約 $60 \mathrm{~km}$ も前 面にあるにもかかわらず，日本の $42 \sim 60^{\circ} \mathrm{C}$ の全 温泉の放熱量の $16 \%$ 占め, $6.3^{\circ} \mathrm{C} / 100 \mathrm{~m}$ という 火山地帯に匹敵する地温勾配を持つ温泉である (角, 1977)。安藤・中村（1953）は常磐湯本温泉 水の化学組成分析値の報告をするとともに，成因 に関する若干の考察を行ったが，その後は放熱量 の研究（例えば, 角, 1977）が行われたのみであ り, 温泉水の起源, 形成機構, および周辺部にあ る温泉との化学的な相互関係については阿武隈地 域の他の温泉と同様, 全く考察が行われてきてい ない。

そこで本研究では，第一に常磐湯本温泉の放熱 量について考察を行うこととしたい。また，阿武 隈地域全域に分布する温泉水の化学, 同位体組成 について報告し,特に塩濃度が高い(1) 北茨城市か らいわき市，(2)双葉郡（楢葉、富岡抢よび双葉各 町)，および(3) 桑折町に分布する温泉について， その起源, 形成機構および相互関係の考察を行う こととしたい。

\section{II. 地形・地質概説}

茨城県北東部, 福島県東部抢よび宮城県南東部 にまたがる阿武隈地域は，南北 $200 \mathrm{~km}$ ，東西 $60 \mathrm{~km}$ の広がりがある。阿武隈花崗岩類, 阿武隈変成岩 など花崗岩類, 斑れい岩類, 変成岩類からなる主 要部は,標高 300-600m 程度の高原になっている。 最高標高は大滝根山の $1192 \mathrm{~m}$ である。阿武隈高 原の北東部は双葉断層により区切られ, ジュラー 最下部白亜系の相馬中村層群と新第三系・第四系 からなる標高 $100 \mathrm{~m}$ 以下の丘陵地と接している。 一方, 阿武隈高原の南東部は上部白亜系の双葉層 群，古第三系の白水層群扰よび新第三系・第四系
の順に重なっているやはり標高 $100 \mathrm{~m}$ 以下の丘陵 地と接している。相馬中村層群, 双葉層群は海成 層, 白水層群は陸成一海成層, 新第三系は海成層 である。

阿武隈高原の南西部は棚倉構造線により区切ら れ，新第三系・第四系からなる標高 $100 \mathrm{~m}$ 以下の 丘陵地と接している。その西部は足尾帯の一部で

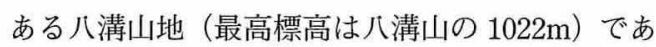
り, 中・古生層からなっている。新第三系は主に 海成層からなる。

阿武隈高原の西部には標高 $100 \mathrm{~m}$ 以下の福島盆 地と, 標高 $300 \mathrm{~m}$ 以下の郡山盆地が位置し, 阿武 隈川が貫流している。新第三系・第四系からなっ ており，いわゆるグリーンタフ地帯の東縁であ る。盆地の西方には春梁山脈が位置している。新 第三系は海成層あるいは陸水成層からなる（日本 の地質「東北地方」編集委員会 (1989）を参照)。

\section{III. 試料と分析}

温泉水および湧水試料の採取は，阿武隈高原お よびその周辺部より行った。調査地域には, 阿武 隈川の西岸地域打よび八溝山と阿武隈高原に挟ま れた大子地域も含まれる。温泉水試料の採取地点 を Fig. 1 に, 聞取り調查などにより得られた坑井 深度など温泉諸元を Table 1 に，それぞれ示した。 採取した試料数は 167 である。

現地で温泉水試料の水温, $\mathrm{pH}$, 電気伝導度の測 定を行った。化学および同位体組成の測定は以下 のように行った。

重炭酸イオン濃度： $\mathrm{pH} 4.8$ アルカリ度より換算. 化学組成: $0.2 \mu \mathrm{m}$ のセルロースアセテートフィル ターで温泉水試料を濾過後, イオンクロマトグラ フ Dionex DX-500 modelにより, $\mathrm{Cl}^{-}, \mathrm{SO}_{4}^{2-}, \mathrm{F}^{2}$, $\mathrm{Br}^{-}, \mathrm{NO}_{2}^{-}, \mathrm{NO}_{3}^{-}$, および $\mathrm{PO}_{4}^{3-}$ の 7 成分の分析を 行った。陰イオン分析用の溶離液は水酸化カリウ ムで, 濃度を $1 \mathrm{~m} . \mathrm{mol}$ から $35 \mathrm{~m} . \mathrm{mol}$ に順次変化さ せるグラディエント分析を行った。

水の水素・酸素同位体組成分析: 水素同位体組成 は亜鉛を用いた水一水素還元法 (バッチ法), 酸 


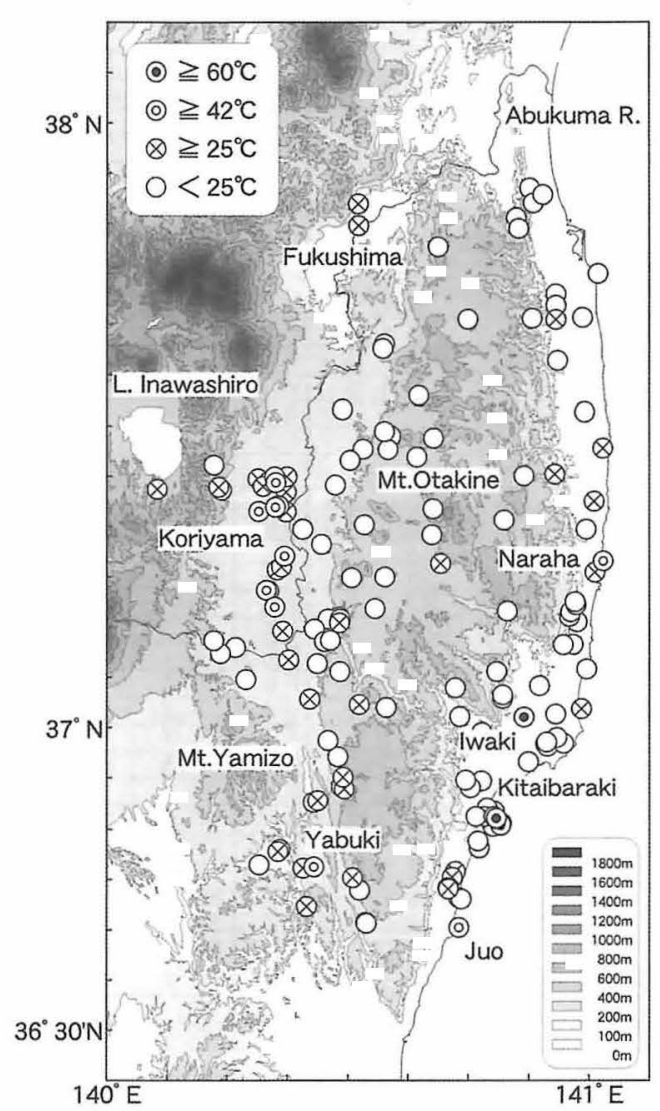

Fig. 1 Locality map of sampling points and distribution map of water temperatures of sampled hot spring waters

素同位体組成は二酸化炭素- 水自動平衡法をそれ ぞれ前処理とする質量分析法により測定した。用 いた測定装置は Finnigan-MAT Delta-S model。測 定䛊差は水素同位体組成で士 $1 \%$, 酸素同位体組 成で士 $0.1 \%$ である。

分析結果を Table 1 に示した。

\section{N. 結果と考察}

\section{1. 水温}

Fig. 1 に阿武隈地域の温泉水の泉温分布を示し
た。 $25^{\circ} \mathrm{C}$ 以上の温泉は 56 ヶ所あり, 最高温度の 温泉は五浦温泉（茨城県北茨城市）の $72^{\circ} \mathrm{C}$ であっ た。 $60^{\circ} \mathrm{C}$ 以上の高々温温泉は, 他に平潟港温泉 $\left(64^{\circ} \mathrm{C}\right.$, 北茨城市) と常磐湯本温泉 $\left(60^{\circ} \mathrm{C}\right.$, 福島 県いわき市) の 2 ヶ所があり, $42^{\circ} \mathrm{C}$ 以上の高温温 泉は, 上記の五浦温泉 $\left(58^{\circ} \mathrm{C}\right)$ の他, あゆり温泉 $\left(51^{\circ} \mathrm{C}\right.$, 福島県矢吹町 $)$, 鵜の岬荘 $\left(46^{\circ} \mathrm{C}\right.$, 茨城県 十王町), ならは天神岬温泉 $\left(43^{\circ} \mathrm{C}\right.$, 福島県楢葉 町）および郡山市など阿武隈川の西岸地域にある 9 温泉の計 13 ヶ所であった。また, $25^{\circ} \mathrm{C}$ 以上の温 泉の大部分は上記温泉の周辺, すなわち阿武隈地 域の高原部分以外の地域に分布していることは，

Fig. 1 から明白である。

常磐湯本温泉の放熱量, $10^{9.6} \mathrm{cal} / \mathrm{min}$ は, 日本の $42 \sim 60^{\circ} \mathrm{C}$ の全温泉の $16 \%$ 占め, 温泉の熱階級 (Fukutomi，1961) はVII *1 に達するなど異常に大 きく, 地殻熱流量による加熱機構以外の何らかの 熱源が存在する必然性が述べられている（中村 · 安藤, 1953; 角, 1977)。ただ, 温泉放熱量の計算 に用いられたのは, 水温 $55.6^{\circ} \mathrm{C}$, 湧出量約 $62 \mathrm{ton} /$ min という值である (角, 1977)。中村·安藤 (1953) は, 常磐炭田の大部分を占める常磐炭砿坑内から の総排水量が約 100 ton $/ \mathrm{min}$, その内 $75 \sim 80 \%$ が 温泉水で占められていると述べているので, 62 ton/min という湧出量值は, 常磐炭田全域からの 総出湯量に近い值である。62ton $/ \mathrm{min}$ という湧出 量值自体, 大きな湧出池を持つ草津湯畑の 3.6 ton $/ \mathrm{min}^{* 2}$, 玉川大噴の $8.4 \mathrm{ton} / \mathrm{min}^{* 3}$ という湧出 量値と比較しても相当に大きな值である。また， 中村·安藤（1953）を見ると, 常磐炭田坑内から 湧出する温泉の水温は, 南部 (常磐炭矿磐崎砿) では $60^{\circ} \mathrm{C}$ 以上であるが, 北部 (常磐炭硡隣の好間 炭矿)では $30^{\circ} \mathrm{C}$ 未満の場所も存在している。これ らのことから, 常磐湯本温泉の放熱量, $10^{9.6} \mathrm{cal} /$ min という值は過剩見積りである可能性があると 考えられる。

\footnotetext{
*1: 温泉の熱階級とは, 温泉地からの放熱量を $10^{6.5} \mathrm{cal} / \mathrm{min}$ 以下を $0,10^{6.5} \sim 10^{7.0} \mathrm{cal} / \mathrm{min}$ を I のように $10^{0.5} \mathrm{cal} / \mathrm{min}$ 刻 みに区分したもの. 熱階級VII 区分される温泉地の放熱量は $10^{9.5} \sim 10^{10.0} \mathrm{cal} / \mathrm{min}$ である.

*2: データの出典は, http://tabijozu.ne.jp/area/kanto/kusatsu/.

*3: $:$ データの出展は, http://www.yukemuri.jp/akita/tamagawa.html/.
} 
Table 1 Chemical and isotopic compositions of hot spring waters taken from Abukuma area

\begin{tabular}{|c|c|c|c|c|c|c|c|c|c|c|}
\hline No. & \begin{tabular}{|c|} 
For \\
Fig. 8 \\
\end{tabular} & Sample name & $\begin{array}{c}\text { sampling } \\
\text { date }\end{array}$ & $\begin{array}{l}\text { Temp. } \\
\left({ }^{\circ} \mathrm{C}\right)\end{array}$ & $\mathrm{pH}$ & $\begin{array}{c}\mathrm{EC} \\
(\mu \mathrm{s} / \mathrm{cm})\end{array}$ & $\begin{array}{c}\mathrm{CI} \\
(\mathrm{mg} / \mathrm{I})\end{array}$ & $\begin{array}{c}\mathrm{S} 04 \\
(\mathrm{mg} / \mathrm{l})\end{array}$ & $\begin{array}{l}\mathrm{HCO3} \\
(\mathrm{mg} / \mathrm{l})\end{array}$ & $\begin{array}{c}F \\
(\mathrm{mg} / \mathrm{l})\end{array}$ \\
\hline \multicolumn{11}{|c|}{ Ibaraki Prefecture } \\
\hline 1 & & Kikunoyu & 2001.11 .09 & 17.3 & 8.5 & 1960 & 415. & 3. 879 & 567. & 0.593 \\
\hline 2 & & $\begin{array}{l}\text { Yasuraginooka } \\
\text { (Takahagi) Spa Hospital }\end{array}$ & 2001.11 .08 & 17.1 & 8. 1 & 310 & 25.6 & 0.352 & 742. & 0.019 \\
\hline 3 & & Otakaji & 2001.11 .15 & 27.6 & 9.0 & 840 & 20.0 & 264. & 65.9 & 11.5 \\
\hline 4 & & Kukainoyu & 2001.11 .15 & 28.1 & 8. 9 & 1410 & 48.5 & 561. & 59.2 & 13.0 \\
\hline 5 & & Hor ikawa-1 & 2001.11 .15 & 32.6 & 8.6 & 2800 & 125. & 1290. & 28.1 & 8.729 \\
\hline 6 & & Hor i kawa-2 & 2001.11 .15 & 20.3 & 7.0 & 1170 & 57.1 & 85.6 & 466. & 1.535 \\
\hline 7 & & Sekison & 2001.11 .09 & 12.9 & 6.6 & 680 & 43.6 & 94.2 & 262. & 0.175 \\
\hline 8 & 0 & Hirakatako & 2001.11 .15 & 64.2 & 7.9 & 19500 & 7640. & 5.48 & 18.7 & 3.188 \\
\hline 9 & & Tomonoyu & 2001.11 .08 & 18.9 & 7.0 & 590 & 30.8 & 179. & 107. & 0.233 \\
\hline 10 & 0 & Joban Uguisudani & 2001.11 .08 & 16.1 & 8.1 & 200 & 597. & 17.8 & 171. & 0.493 \\
\hline 11 & & Isohara-1 & 2001.11 .08 & 16.8 & 8.9 & 540 & 54.2 & 57.0 & 198. & 0.201 \\
\hline 12 & 0 & Isohara-2 & 2001.11 .08 & 17.1 & 7.9 & 640 & 1560. & 189. & 205. & \\
\hline 13 & & Yunoami & 2001.11 .15 & 13.2 & 6.4 & 1030 & 223. & 97.8 & 75.2 & 0.265 \\
\hline 14 & & Sekiyama-1 & 2001.11 .09 & 15.0 & 9.2 & 550 & 29.2 & 43.7 & 248. & 0.381 \\
\hline 15 & & Sekiyama-2 & 2001.11.09 & 18.2 & 8.7 & 670 & 24.9 & 140. & 221. & 0.211 \\
\hline 16 & & Iwabana & 2001.11 .09 & 14.2 & 7.0 & 440 & 25.3 & 54.3 & 142. & 0.091 \\
\hline 17 & 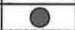 & Otsuko & 2001.11 .09 & 16.3 & 7.8 & 1240 & 347. & 23.0 & 168. & \\
\hline 18 & 0 & Izura-1 & 2001.11 .15 & 72.3 & 7.6 & 18700 & 7060. & 53.8 & 28.6 & 3.468 \\
\hline 19 & 0 & Izura-2 & 2001.11 .15 & 38.3 & 8.2 & 5300 & 1590. & 0.247 & 477. & 1.45 \\
\hline 20 & 0 & Izura-3 & 2001.11 .15 & 57.5 & 8. 0 & $>20000$ & 7710. & 11.6 & 29.6 & 3.816 \\
\hline 21 & & Yokokawa & 2001.11 .09 & 13.8 & 10.2 & 380 & 21.3 & 29.6 & 99.8 & 5.257 \\
\hline 22 & & Osuge & 2001.11 .09 & 15.4 & 9.9 & 390 & 33.4 & 34.9 & 74.4 & 6.685 \\
\hline 23 & & Isago & 2001.11 .09 & 10.0 & 9.7 & 350 & 26.2 & 28.5 & 92.5 & 5.937 \\
\hline 24 & & Satomi & 2001.11 .09 & 32.6 & 10.1 & 400 & 42.3 & 10.3 & 96.1 & 9.201 \\
\hline 25 & & Daigo & 2001.11 .08 & 29.2 & 8.7 & 1480 & 160. & 513. & 41.5 & 6.575 \\
\hline 26 & & Asakawa-1 & 2001.11 .08 & 25.9 & 9.0 & 1480 & 170. & 517. & 37.0 & 6.636 \\
\hline 27 & & Asakawa-2 & 2001.11 .08 & 15.6 & 6.8 & 160 & 4. 659 & 4. 469 & 76.4 & 0.086 \\
\hline 28 & & Fukuroda-1 & 2001.11 .09 & 38.6 & 8. 9 & 640 & 33.5 & 158. & 110. & 8.797 \\
\hline 29 & & Fukuroda-2 & 2001.11 .09 & 37.0 & 8. 9 & 650 & 34.6 & 158. & 105. & 8.71 \\
\hline 30 & & Shionosawa & 2001.11 .08 & 13.1 & 8. 2 & 550 & 6.697 & 64.5 & 281. & 0.753 \\
\hline 31 & & Yuzawa & 2001.11 .09 & 26.0 & 8.8 & 1160 & 147. & 306. & 62.9 & 10.1 \\
\hline 32 & & Tsukiori & 2001.11 .09 & 42.5 & 8.9 & 660 & 31.7 & 158. & 103. & 11.4 \\
\hline 33 & & Unomisaki & 2001.11 .08 & 46.1 & 8.9 & 330 & 128. & 1450. & 28.4 & 6.82 \\
\hline \multicolumn{11}{|c|}{ Fukushima Prefecture } \\
\hline 34 & & Kor i yama & 2001.11 .09 & 31.3 & 8. 9 & 1230 & 139. & 301. & 101. & 9. 387 \\
\hline 35 & & Gendanoyu & 2001.11 .09 & 16.2 & 8.3 & 440 & 18.6 & 147. & 48.6 & 1.416 \\
\hline 36 & & Nakatsugawa & 2001.11 .06 & 11.8 & 6.6 & 68 & 1. 219 & & 23.7 & 0.035 \\
\hline 37 & & Mor i yama & 2001.11 .05 & 17.4 & 6.6 & 320 & 5.491 & 13.8 & 102. & 0.031 \\
\hline 38 & & Mor iyama & 2001.11 .06 & 17.3 & 6.2 & 194 & 16.3 & 15.4 & 53.7 & 0.104 \\
\hline 39 & & Mihoda & 2001.11 .06 & 44.3 & 8.5 & 1060 & 112. & 215. & 164. & 2. 63 \\
\hline 40 & & Tohokuhara & 2001.11 .09 & 41. 0 & 8.5 & 1280 & 114. & 167. & 365. & 11.5 \\
\hline 41 & & Ishibashi-1 & 2001.11 .06 & 44.8 & 8.6 & 1840 & 438. & 179. & 146. & 17.0 \\
\hline 42 & & Ishibashi-2 & 2001.11 .06 & 48.9 & 8.7 & 1910 & 256. & 503. & 67.2 & 6.635 \\
\hline 43 & & Gekko & 2001.11 .05 & 41.9 & 8.6 & 980 & 129. & 83.1 & 229. & 11.5 \\
\hline 44 & & Yasumi ishi & 2001.11 .06 & 29.8 & 9. 1 & 2000 & 158. & 840. & 18.7 & 2. 548 \\
\hline 45 & & Uneme & 2001.11 .05 & 43.3 & 7.9 & 2300 & 232. & 171. & 825. & 6.037 \\
\hline 46 & & Goreibitsu & 2001.11 .05 & 19.1 & 9.0 & 870 & 46.0 & 385. & 18.5 & 2. 007 \\
\hline 47 & & Konan & 2001.11 .06 & 41.0 & 8.7 & 570 & 3.43 & 107. & 86.3 & 0.954 \\
\hline 48 & & Kor iyama Yumoto & 2001.11 .09 & 40.0 & 8.6 & 1390 & 209. & 324. & 101. & 7. 199 \\
\hline 49 & & Kosai Tsutsumi & 2001.11 .05 & 42.9 & 8.4 & 1630 & 179. & 327. & 301. & 8.238 \\
\hline 50 & & Narita & 2001.11 .05 & 43.3 & 8. 3 & 550 & 28.3 & 1. 371 & 273. & 1.596 \\
\hline 51 & & Namiki & 2001.11 .06 & 36.4 & 9.0 & 2200 & 15.7 & 22.6 & 51.1 & 0.465 \\
\hline 52 & & Yaji-1 & 2001.11 .15 & 15.2 & 10.3 & 370 & 9.671 & 27.1 & 165. & 0.66 \\
\hline 53 & & Yaji-2 & 2001.11 .15 & 15.6 & 10.3 & 350 & 10.2 & 28.1 & 157. & 0.664 \\
\hline 54 & & Yaji-3 & 2001.11 .15 & 16.0 & 10.3 & 380 & & & 160. & \\
\hline 55 & & Kunohama & 2001.11 .15 & 14.6 & 10.1 & 380 & 7. 32 & 14.9 & 185. & 0.396 \\
\hline 56 & & Ir imazawa & 2001.11 .15 & 15.2 & 8.8 & 230 & 7. 399 & 22.5 & 103. & 0.141 \\
\hline 57 & & Tamayama & 2001.11 .14 & 12.6 & 10.0 & 410 & 7.03 & 28.4 & 198. & 0.563 \\
\hline 58 & & Shiraiwa & 2001.11 .14 & 13.5 & 4. 1 & 1000 & 15.4 & 622. & 0.00 & 0.782 \\
\hline 59 & & Narusawa & 2001.11 .15 & 15.5 & 10.0 & 510 & 5.498 & 14.9 & 265. & 0.251 \\
\hline 60 & (2) & Yotsukura Maiko & 2001.11 .14 & 17.8 & 7.2 & 4100 & 1480. & 0.302 & 184. & \\
\hline 61 & & Sawanoyu-1 & 2001.11 .15 & 17.3 & 6.4 & 300 & 13.8 & 70.8 & 40.7 & 0.064 \\
\hline 62 & & Sawanoyu-2 & 2001.11 .15 & 13.8 & 6.5 & 310 & 10.9 & 81.4 & 39.4 & 0.047 \\
\hline 63 & (2) & Iwaki Shin-Maiko & 2001.11 .14 & 37.4 & 7.9 & 7400 & 2840 . & 21.4 & 88.8 & 3.581 \\
\hline 64 & (a) & Iwaki Yumoto & 2001.11 .14 & 60.0 & 8.6 & 3100 & 622. & 458. & 62.9 & 5.319 \\
\hline 65 & & Yoshinotani-1 & 2001.11 .14 & 12.0 & 7.1 & 240 & 10.1 & 38.4 & 85.1 & 0.059 \\
\hline 66 & & Yoshinotani-2 & 2001.11 .14 & 13.0 & 7.1 & 260 & 7.90 & 37.6 & 70.3 & 0.133 \\
\hline 67 & & Yoshinotani-3 & 2001.11 .14 & 13.7 & 7.1 & 250 & 5.142 & 30.0 & 95.2 & 0.104 \\
\hline 68 & & Nakanenoyu & 2001.11 .14 & 11.6 & 6.8 & 111 & 5.704 & 4. 24 & 43.1 & 0.053 \\
\hline 69 & & Koya-1 & 2001.11 .15 & & 10.0 & 370 & 3.721 & 13.0 & 194. & 0.115 \\
\hline
\end{tabular}




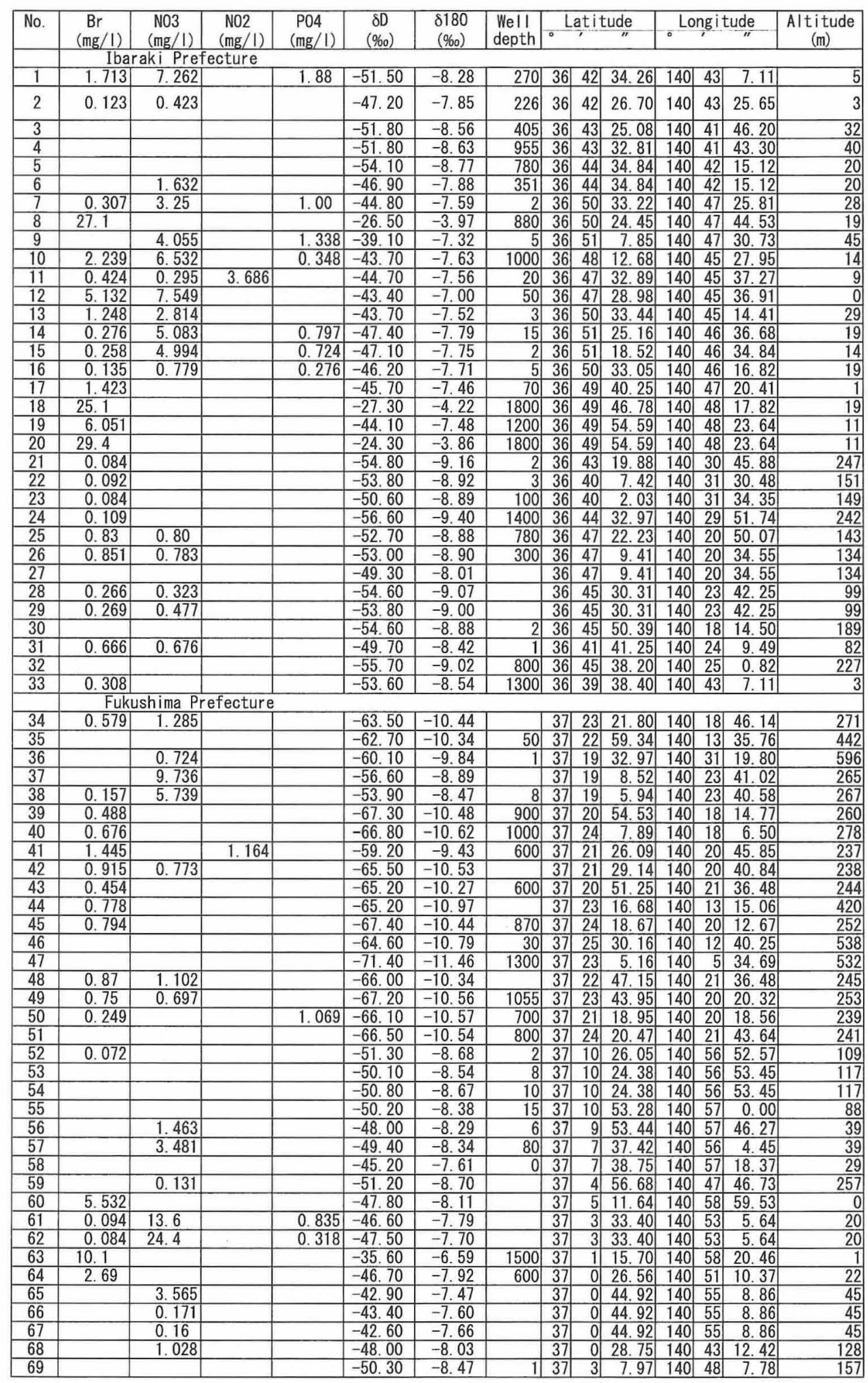




\begin{tabular}{|c|c|c|c|c|c|c|c|c|c|c|}
\hline No. & \begin{tabular}{|c|} 
For \\
Fig. 8
\end{tabular} & Sample name & $\begin{array}{l}\text { sampling } \\
\text { date }\end{array}$ & $\begin{array}{l}\text { Temp. } \\
\left({ }^{\circ} \mathrm{C}\right)\end{array}$ & $\mathrm{pH}$ & $\begin{array}{c}\mathrm{EC} \\
(\mu \mathrm{s} / \mathrm{cm})\end{array}$ & $\begin{array}{c}\mathrm{Cl} \\
(\mathrm{mg} / \mathrm{l})\end{array}$ & $\begin{array}{c}\mathrm{SO4} \\
(\mathrm{mg} / \mathrm{I})\end{array}$ & $\begin{array}{l}\mathrm{HCO3} \\
(\mathrm{mg} / \mathrm{I})\end{array}$ & $\begin{array}{c}F \\
(\mathrm{mg} / \mathrm{I})\end{array}$ \\
\hline 70 & & Koya-2 & 2001.11 .16 & 14.3 & 10.4 & 390 & 3.432 & 12.3 & 205. & 0.29 \\
\hline 71 & & Koya-3 & 2001.11 .15 & 19.1 & 10.1 & 370 & 4.725 & 14.8 & 193. & 0.392 \\
\hline 72 & & Zuya & 2001.11 .15 & 15.4 & 8.1 & 370 & 6.284 & 58.9 & 122. & 0.514 \\
\hline 73 & & Kotaki & 2001.11 .14 & 16.0 & 7.0 & 90 & 40.8 & 270. & 179. & 0.121 \\
\hline 74 & & Harakida & 2001.11 .15 & 14.7 & 7.1 & 730 & 19.1 & 282. & 132. & 0.225 \\
\hline 75 & & Kanchiyama & 2001.11 .15 & 9.6 & 6.7 & 280 & 15.7 & 73.5 & 37.0 & 0.067 \\
\hline 76 & & Kajiro & 2001.11 .14 & 11.3 & 9.0 & 1810 & 316. & 268. & 334. & 0.466 \\
\hline 77 & & Jikiri & 2001.11 .14 & 13.1 & 7.3 & 590 & 13.5 & 221. & 126. & 0.194 \\
\hline 78 & & Shimokawanoyu & 2001.11 .15 & 14.2 & 7.2 & 1400 & 83.0 & 435. & 218. & 0.27 \\
\hline 79 & & Kawabe & 2001.11 .14 & 11.5 & 9.7 & 480 & 7.953 & 38.2 & 200. & 0.518 \\
\hline 80 & & Nishiki & 2001.11 .14 & 16.1 & 5.7 & 106 & 9.926 & 14.9 & 11.1 & 0.018 \\
\hline 81 & & Shiroyone & 2001.11 .14 & 15.8 & 7.1 & 320 & 23.1 & 14.3 & 117. & 0.073 \\
\hline 82 & & Kinshoji-1 & 2001.11 .06 & 12.1 & 6.0 & 38 & 1.627 & 4.306 & 13.7 & \\
\hline 83 & & Kinshoji-2 & 2001.11 .06 & 14.6 & 5.9 & 91 & 7.991 & 12.0 & 17.3 & 0.059 \\
\hline 84 & & Mamegara Fudoson & 2001.11 .06 & 12.2 & 6.9 & 77 & 2. 335 & 0.714 & 43.1 & \\
\hline 85 & & Omura & 2001.11 .06 & 14.3 & 6.6 & 410 & 24.7 & 74.5 & 104. & 0.04 \\
\hline 86 & & Nittagawa & 2001.11 .13 & 25.5 & 8. 9 & 1700 & 486. & 1.283 & 149. & 11.0 \\
\hline 87 & & Serizawa & 2001.11 .06 & 48.4 & 9.0 & 510 & 23.7 & 2.008 & 259. & 3.825 \\
\hline 88 & & Kabaniwa & 2001.11 .13 & 14.6 & 7.3 & 200 & 16.3 & 6.437 & 78.1 & 0.032 \\
\hline 89 & & Kori & 2001.11 .16 & 27.6 & 8.3 & 9800 & 1800. & 1080. & 218. & 2.278 \\
\hline 90 & & Shirasawa-1 & 2001.11 .07 & 15.8 & 6.6 & 570 & 33.2 & 0.685 & 206. & 0.248 \\
\hline 91 & & Shirasawa-2 & 2001.11 .07 & 15.8 & 7.0 & 240 & 26.4 & 13.5 & 51.3 & 0.061 \\
\hline 92 & & Marunaka & 2001.11 .05 & 37.6 & 9.0 & 500 & 34.3 & 0.322 & 234. & 3. 627 \\
\hline 93 & & Kagami ishi & 2001.11 .05 & 31.4 & 9.0 & 300 & 6.869 & 0.284 & 176. & 1.588 \\
\hline 94 & & Shin-Kikushima & 2001.11 .05 & 38.6 & 8.3 & 164 & 2.851 & 0.943 & 93.7 & 1.189 \\
\hline 95 & & Yanaka & 2001.11 .05 & 14. 4 & 7.2 & 114 & 1.155 & 1.969 & 75.2 & 0.109 \\
\hline 96 & & Kitsuneuchi & 2001.11 .05 & 29.9 & 9.3 & 370 & 8.29 & & 194. & 1.359 \\
\hline 97 & & Naka jima & 2001.11 .05 & 38.4 & 9.2 & 380 & 18.6 & 0.206 & 192. & 1.804 \\
\hline 98 & & Ayur i & 2001.11 .05 & 50.9 & 8.8 & 900 & 85.1 & 0.813 & 391. & 6.001 \\
\hline 99 & & Kan' nonyu & 2001.11 .05 & 53.6 & 9.2 & 520 & 33.1 & 1. 777 & 250. & 2. 886 \\
\hline 100 & & Tanakura & 3001.11 .08 & 27.1 & 9.6 & 290 & 1.127 & 2. 865 & 167. & 0.287 \\
\hline 101 & & Takinosawa-1 & 2001.11 .08 & 11.5 & 9.7 & 530 & 4.783 & 42.9 & 260. & 1.266 \\
\hline 102 & & Takinosawa-2 & 2001.11 .08 & 10.8 & 9.7 & 360 & 3.088 & 27.9 & 154. & 0.74 \\
\hline 103 & & Higashidate & 2001.11 .07 & 26.6 & 10.1 & 470 & 28.1 & 25.0 & 150. & 12.3 \\
\hline 104 & & Tsukise & 2001.11 .07 & 13.6 & 8.2 & 810 & 17.9 & 2. 316 & 483. & 4.848 \\
\hline 105 & & Yujimata-1 & 2001.11 .07 & 37.2 & 9.8 & 210 & 4.523 & 10.9 & 82.6 & 0.82 \\
\hline 106 & & Yujimata-2 & 2001.11 .07 & 38.2 & 9.7 & 210 & 4. 396 & 10.6 & 92.5 & 0.796 \\
\hline 107 & & Shin-Yujimata & 2001.11 .07 & 29.2 & 9.7 & 147 & 3.734 & 7.456 & 74.0 & 0.469 \\
\hline 108 & & Tanigawa & 2001.11 .07 & 14.3 & 10.0 & 210 & 2. 694 & 10.3 & 103. & 0.469 \\
\hline 109 & & Shihonoyu & 2001.11 .07 & 28.6 & 9.8 & 260 & 7.927 & 17.2 & 109. & 1.537 \\
\hline 110 & & Yunota & 2001.11 .07 & 25.5 & 9.6 & 147 & 3.927 & 9.896 & 51.3 & 0.679 \\
\hline 111 & & Bobata-1 & 2001.11 .06 & 20.0 & 10.0 & 192 & 9.946 & 9. 219 & 81.4 & 0.753 \\
\hline 112 & & Bobata-2 & 2001.11 .06 & 14.0 & 10.0 & 173 & 7.958 & 9.592 & 75.2 & 0.867 \\
\hline 113 & & Bobata-3 & 2001.11 .06 & 25.0 & 9. 9 & 145 & 3.491 & 8.19 & 56.7 & 0.232 \\
\hline 114 & & Hageyama & 2001.11 .06 & 16.3 & 6.3 & 78 & 2. 607 & 6.235 & 29.6 & 0.032 \\
\hline 115 & & Nar igame & 2001.11 .06 & 14.9 & 7.0 & 120 & 4.60 & 1.953 & 58.6 & 0.077 \\
\hline 116 & & Nekonaki & 2001.11 .07 & 14.1 & 10.0 & 160 & 5.048 & 9.512 & 75.7 & 0.335 \\
\hline 117 & & Katakura & 2001.11 .06 & 13.7 & 7.0 & 131 & 5.752 & 3. 607 & 52.5 & 0.045 \\
\hline 118 & & Shionosawa-1 & 2001.11 .07 & 20.7 & 9.8 & 128 & 3. 899 & 8. 881 & 63.5 & 0.237 \\
\hline 119 & & Shionosawa-2 & 2001.11 .07 & 13.7 & 6.9 & 73 & 1.892 & 0.482 & 34.5 & 0.054 \\
\hline 120 & & Yotsutsuji & 2001.11 .06 & 13.9 & 6.1 & 101 & 6.111 & 6.352 & 22.2 & 0.098 \\
\hline 121 & & Mayumi & 2001.11 .06 & 13.8 & 6.2 & 185 & 4. 941 & 14.0 & 71.5 & 0.046 \\
\hline 122 & & Kajikanosato & 2001.11 .07 & 11.5 & 6.1 & 139 & 3.421 & 6.055 & 46.8 & 0.014 \\
\hline 123 & & Asakawa & 2001.11 .06 & 14.6 & 6.2 & 172 & 8.542 & 18.4 & 73.2 & 0.042 \\
\hline 124 & & Nyudo & 2001.11 .07 & 12.6 & 10.4 & 380 & 22.6 & 6.073 & 134. & 11.9 \\
\hline 125 & & Babanoyu & 2001.11 .07 & 16.5 & 7.3 & 171 & 6.95 & 8. 782 & 76.4 & 0.299 \\
\hline 126 & & Saitonoyu & 2001.11 .08 & 12.9 & 6.5 & 230 & 9.659 & 26.2 & 74.0 & 0.062 \\
\hline 127 & & Yawarag inoyu & 2001.11 .07 & 13.7 & 6.5 & 199 & 10.4 & 19.9 & 55.5 & 0.139 \\
\hline 128 & & Yuzawa & 2001.11 .07 & 26.9 & 9.6 & 120 & 3.702 & 7. 074 & 60.4 & 0.207 \\
\hline 129 & & Hariyu & 2001.11 .07 & 16.5 & 9.5 & 115 & 4.363 & 7.511 & 41.5 & 0.131 \\
\hline 130 & & Kanda & 2001.11 .08 & 14.7 & 9.3 & 128 & 10.8 & 5.978 & 59.8 & 1.032 \\
\hline 131 & & Hidokoronoyu & 2001.11 .07 & 11.4 & 6.5 & 88 & 2. 236 & 3.916 & 36.1 & 0.061 \\
\hline 132 & & Kanameta & 2001.11 .08 & 14.3 & 6.7 & 350 & 6.461 & 7.248 & 184. & 0.131 \\
\hline 133 & & Izumi & 2001.11 .07 & 14.2 & 6.9 & 260 & 9.083 & 11.9 & 47.6 & 0.02 \\
\hline 134 & & Hananoyu & 2001.11 .08 & 12.6 & 6.6 & 92 & 5.30 & & 46.8 & 0.058 \\
\hline 135 & & Oriki & 2001.11 .15 & 10.7 & 10.0 & 360 & 8.045 & 24.5 & 142. & 0.423 \\
\hline 136 & & Oriki-Menoyu & 2001.11 .15 & 13.0 & 3. 0 & 800 & 9.84 & 263. & 0.00 & 0.372 \\
\hline 137 & & Naraha-Ten j inmosaki & 2001.11 .15 & 43.2 & 8.6 & 2600 & 674. & 3. 696 & 408. & 0.709 \\
\hline 138 & & Iwaido & 2001.11 .14 & 11.4 & 7.5 & 250 & 7.074 & 25.0 & 92.7 & 0.086 \\
\hline 139 & & Tamanoyu & 2001.11 .14 & 25.8 & 9.8 & 210 & 6.519 & 17.9 & 65.3 & 0.584 \\
\hline 140 & & Karo & 2001.12 .20 & 12.9 & 8.0 & 200 & 5.528 & 7.41 & 102. & 0.058 \\
\hline 141 & & Bekonoyu & 2001.11 .13 & 12.3 & 7.5 & 410 & 5.035 & 5.332 & 111. & 0.061 \\
\hline
\end{tabular}




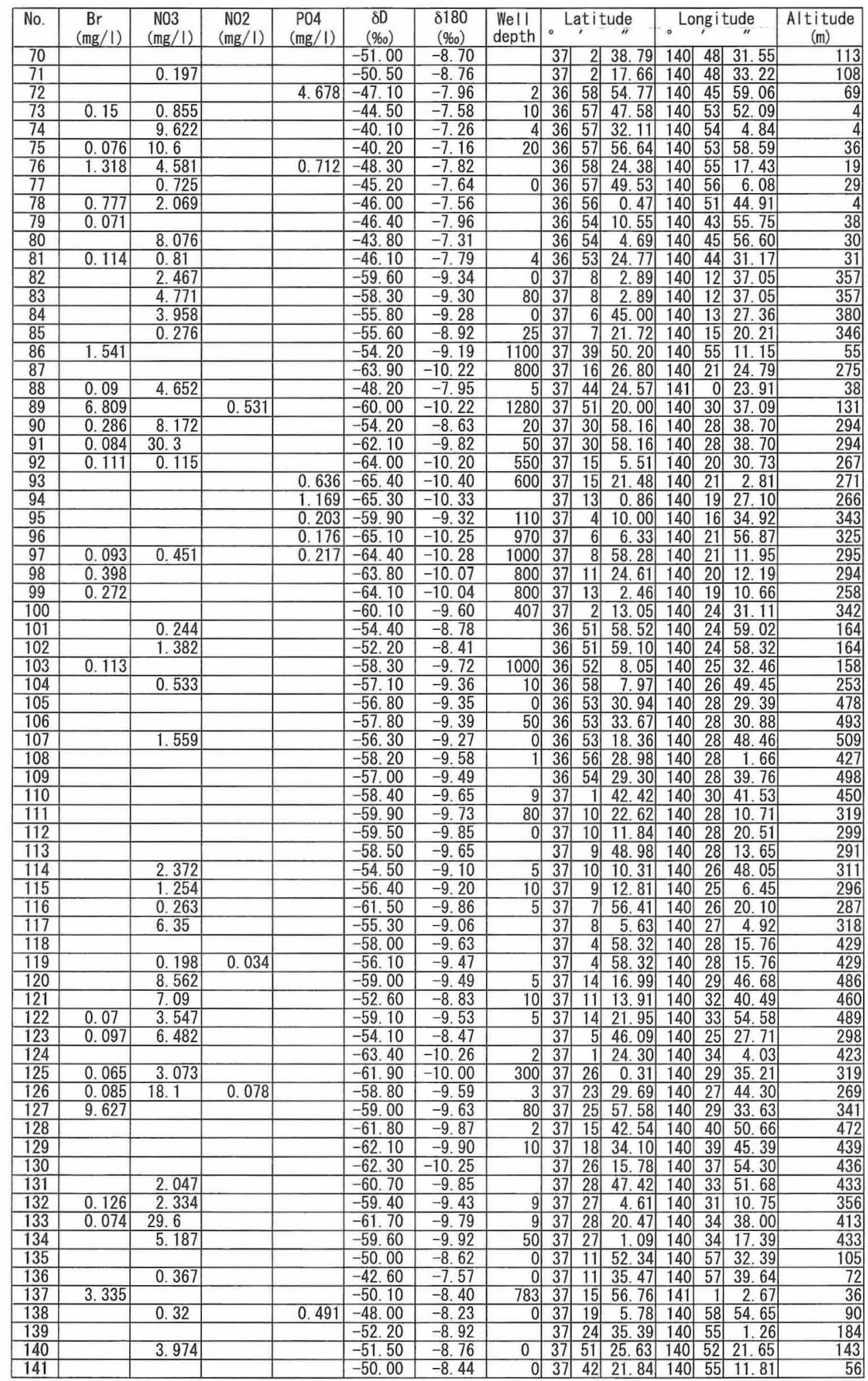




\begin{tabular}{|c|c|c|c|c|c|c|c|c|c|c|}
\hline No. & \begin{tabular}{|c} 
For \\
Fig. 8 \\
\end{tabular} & Sample name & $\begin{array}{c}\text { sampl ing } \\
\text { date }\end{array}$ & $\begin{array}{l}\text { Temp. } \\
\left({ }^{\circ} \mathrm{C}\right)\end{array}$ & $\mathrm{pH}$ & $\begin{array}{c}\mathrm{EC} \\
(\mu \mathrm{s} / \mathrm{cm})\end{array}$ & $\begin{array}{c}\mathrm{Cl} \\
(\mathrm{mg} / \mathrm{I})\end{array}$ & $\begin{array}{c}\mathrm{SO} 4 \\
(\mathrm{mg} / \mathrm{I})\end{array}$ & $\begin{array}{l}\mathrm{HCO3} \\
(\mathrm{mg} / \mathrm{I})\end{array}$ & $\begin{array}{c}F \\
(\mathrm{mg} / \mathrm{l})\end{array}$ \\
\hline 142 & & Kazaananoyu & 2001.12 .20 & 10.0 & 7.3 & 220 & 5. 218 & 8.71 & 133. & 0.04 \\
\hline 143 & & Kawagonoyu & 2001.11 .13 & 8.7 & 6.6 & 75 & 12.4 & 2.384 & 13.6 & \\
\hline 144 & 0 & Naraha-Haguroyama & 2001.11 .15 & 36.5 & 7.7 & $>20000$ & 12900. & 1.341 & 51.8 & \\
\hline 145 & & Tenzannoyu & 2001.11 .14 & 19.8 & 10.4 & 310 & 10.9 & 11.1 & 144. & 2.688 \\
\hline 146 & 0 & Sakuranoyu & 2001.11 .15 & 39.1 & 7.8 & $>20000$ & 10900. & 2. 143 & 22.0 & \\
\hline 147 & & Utsumine & 2001.11 .06 & 14.5 & 6.1 & 186 & 14.0 & 14.2 & 43.1 & 0.029 \\
\hline 148 & & Deguchi & 2001.11 .14 & 14.1 & 4.0 & 1210 & 67.2 & 543. & 0.00 & 0.412 \\
\hline 149 & & Baba & 2001.11 .14 & 14.5 & 6.6 & 125 & 8.433 & 11.8 & 34.5 & 0.058 \\
\hline 150 & & Ohara & 2001.11 .14 & 12.8 & 7.8 & 200 & 4. 328 & 6.982 & 98.6 & 0.058 \\
\hline 151 & & Setogaro & 2001.11 .16 & 11.3 & 6.6 & 61 & 3.487 & 2.545 & 13.4 & 0.052 \\
\hline 152 & & Nakago & 2001.11 .09 & 35.6 & 8.5 & 300 & 148. & 1420. & 30.8 & 7.643 \\
\hline 153 & & Skypalace Tokiwa & 2001.11 .08 & 11.7 & 6.5 & 94 & 3.462 & 2. 186 & 37.4 & 0.038 \\
\hline 154 & & Kobo & 2001.12 .19 & 12.0 & 7.6 & 75 & 2.508 & & 45.2 & 0.05 \\
\hline 155 & & Hoshonomura Fureai & 2001.12 .19 & 11.3 & 6.8 & 88 & 3.612 & 4.782 & 31.7 & 0.068 \\
\hline 156 & & Ippai & 2001.11 .13 & 11.5 & 8.1 & 220 & 7.613 & 12.6 & 107. & 0.08 \\
\hline 157 & & Ukon & 2001.11 .13 & 13.1 & 6.5 & 210 & 12.6 & 1. 441 & 52.3 & 0.04 \\
\hline 158 & & Ryozen Yusuinosato & 2001.12 .20 & 10.7 & 8.0 & 59 & 2. 442 & 0.506 & 30.8 & 0.03 \\
\hline 159 & & Noda & 2001.11 .16 & 28.1 & 8.8 & 420 & 41.1 & 44.6 & 109. & 3.353 \\
\hline 160 & 0 & Sendan & 2001.11 .14 & 31.0 & 7.3 & $>20000$ & 14400. & 4. 628 & 22.0 & \\
\hline 161 & & Namezu & 2001.12 .19 & 17.9 & 9.4 & 126 & 6.835 & 7.487 & 57.9 & 1.147 \\
\hline 162 & & Midoriya & 2001.12 .19 & 12.8 & 6.3 & 3100 & 27.2 & 27.6 & 98.6 & \\
\hline 163 & & Chome isui & 2001.11 .14 & 12.8 & 7.8 & 39 & 2.422 & 0.185 & 21.0 & 0.049 \\
\hline 164 & & Nukui & 2001.12 .19 & 15.2 & 8.6 & 138 & 4.035 & 9.666 & 57.4 & 0.182 \\
\hline 165 & & Tennogawa-Tron & 2001.11 .14 & 8.6 & 7.5 & 47 & 2.255 & 0.934 & 17.3 & 0.031 \\
\hline \multicolumn{11}{|c|}{ Miyagi Prefecture } \\
\hline 166 & & Aoba & 2001.11 .13 & 22.1 & 9.8 & 156 & 4. 282 & 5.967 & 62.2 & 1.42 \\
\hline 167 & & Saikawa & 2001.11 .13 & 20.3 & 9.6 & 98 & 3.674 & 3.824 & 53.5 & 0.176 \\
\hline
\end{tabular}

また, 本来温泉の熱階級は自然状態で湧出して いる温泉に対して用いる指標である（Fukutomi， 1961）。常磐湯本温泉の自然状態での放熱量は,

(1)近傍に位置する常磐炭田の開発の始まりが江 戸時代の 1850 年代にまで遡ること（いわき市史編 さん委員会, 1975, p.526)，(2) 明治 38 年 (1905 年) 頃始まった温泉湧出量の減少後に湧出量の測定を 開始していること(温度測定は行われていない)， (3)この段階で既に温泉水は自然湧出ではなくす べて $18 \sim 45 \mathrm{~m}$ (10 間〜 25 間), 最高 $115 \mathrm{~m}$ (63 間) の掘削井より湧出あるいは沙湯していること（中 村，1909）などから，完全に復元することは不可 能であると考えられる。ただ，中村（1909）が記 載した湯本温泉原泉位置図では，原泉が幅 $80 \mathrm{~m}$, 長さ $500 \mathrm{~m}$ の範囲内に南北 2 群あり, 両群とも 3 列の配列を見せていること，また，地質調査所 （1914）が記載した湯本温泉原泉位置図では，湯 本断層の直上に原泉群が位置すること, 原泉群を 取り囲むように江戸時代から温泉宿として栄えて きた湯本の村落があること, 湯本の村落を通る水 戸街道が原泉群近傍で，原泉群を避けるように平 行する 2 道になっていることなどから, 温泉坑井 群は元々自然湧出していた場所の近傍に分布して
いることが考えられる。中村（1909）が記録した 温泉湧出量の最大値は $849 \ell / \mathrm{min}$ (4.7 石/ 分) で ある。水温を現在の常磐湯本温泉と同じ $60^{\circ} \mathrm{C}$ 程度 であったと仮定すると，放熱量は $10^{7.7} \mathrm{cal} / \mathrm{min}$ と なり, 温泉の熱階級は四である。熱階級四の放熱 量の上限は $10^{8.0} \mathrm{cal} / \mathrm{min}$ であり, 水温から逆算さ 机る温泉水の湧出量の上限は $1667 \mathrm{l} / \mathrm{min}$ となる。 Fig. 2 に, 中村 (1909) が記録した明治 38 年 $(1905$ 年) 10 月から明治 42 年 (1909 年) 4 月までの湯本 温泉の湧出量の変化を示した。最初の 1 年間の涌 出量の減少が, 後半の湧出量の減少より大きく, 直線的に約 $300 \mathrm{e} / \mathrm{min}$ も減少していることがわか る。中村 (1909) には, 温泉湧出量の減少が始まっ たのは明治 38 年 5 月と記載されている。温泉涌出 量の減少率が, 明治 38 年 5 月から 10 月までとそれ 以降の 1 年間とが同様であったと仮定すると, 明 治 38 年 5 月当時の湧出量は $975 \mathrm{l} / \mathrm{min}$ 程度になるこ とが Fig. 2 から読み取れる。水温に著しい変化が なければ, 温泉熱階級は範囲内である。福富 （1965）は，温泉熱階級が III 以下の場合は，地殼 熱流量による加熱機構のみで温泉放熱量を説明で きることを示した。ここでいう地殼熱流量とは， 地球内部から地表に向かう熱の流れの意味であ 


\begin{tabular}{|c|c|c|c|c|c|c|c|c|c|c|c|c|c|c|}
\hline \multirow{2}{*}{ No. } & $\mathrm{Br}$ & N03 & N02 & P04 & $\delta D$ & $\delta 180$ & Well & \multirow{2}{*}{\multicolumn{3}{|c|}{ Latitude }} & \multirow{2}{*}{\multicolumn{3}{|c|}{ Long itude }} & \multirow{2}{*}{$\begin{array}{c}\text { Altitude } \\
(\mathrm{m})\end{array}$} \\
\hline & $(\mathrm{mg} / \mathrm{l})$ & $(\mathrm{mg} / \mathrm{I})$ & $(\mathrm{mg} / \mathrm{I})$ & $(\mathrm{mg} / \mathrm{I})$ & $(\% 0)$ & $(\% 0)$ & depth & & & & & & & \\
\hline 142 & & 0.30 & & & -50.60 & -8.67 & 0 & 37 & 41 & 14.88 & 140 & 55 & 11.11 & 61 \\
\hline 143 & & 0.575 & & & -39.40 & -7.09 & 0 & 37 & 40 & 2.73 & 140 & 58 & 28.46 & 19 \\
\hline 144 & 50.7 & & 22.7 & & -26.70 & -4.14 & 1200 & 37 & 14 & 49.38 & 141 & 0 & 0.70 & 27 \\
\hline 145 & & & & & -63.70 & -10.46 & 1500 & 37 & 20 & 0.31 & 140 & 48 & 45.00 & 411 \\
\hline 146 & 34.1 & & 13.2 & & -32.30 & -3.51 & 1500 & 37 & 21 & 52.03 & 140 & 59 & 54.77 & 59 \\
\hline 147 & 0.093 & 15.2 & & & -57.00 & -9.43 & 107 & 37 & 17 & 35.63 & 140 & 26 & 0.76 & 280 \\
\hline 148 & & & & & -46.40 & -7.70 & & 37 & 30 & 42.50 & 140 & 58 & 45.07 & 39 \\
\hline 149 & 0.083 & 7. 139 & & & -49.20 & -8.18 & & 37 & 35 & 47.58 & 140 & 55 & 22.62 & 61 \\
\hline 150 & & 0.837 & & & -49.00 & -8.46 & 0 & 37 & 39 & 58.40 & 140 & 52 & 13.08 & 122 \\
\hline 151 & & 0.834 & & & -45.70 & -8.08 & & 37 & 10 & 58.24 & 140 & 49 & 8.77 & 160 \\
\hline 152 & 0.323 & & & & -50.00 & -8.87 & 800 & 36 & 45 & 9.57 & 140 & 42 & 40.39 & 41 \\
\hline 153 & & 5.803 & & & -63.70 & -10.15 & 25 & 37 & 28 & 9.69 & 140 & 39 & 57.83 & 702 \\
\hline 154 & & 0.174 & & & -61.20 & -10.09 & & 37 & 39 & 52.34 & 140 & 44 & 14.12 & 476 \\
\hline 155 & & 1. 767 & & & -60.00 & -9.57 & 28 & 37 & 21 & 7.77 & 140 & 39 & 55.02 & 521 \\
\hline 156 & & 2. 943 & & 2. 992 & -52.70 & -8.68 & & 37 & 52 & 15.55 & 140 & 53 & 34.07 & 52 \\
\hline 157 & 0.128 & 48.4 & 0.096 & & -51.30 & -8.31 & & 37 & 52 & 54.45 & 140 & 51 & 55.02 & 180 \\
\hline 158 & & & & & -63.00 & -10.44 & 0 & 37 & 47 & 4.38 & 140 & 40 & 34.39 & 587 \\
\hline 159 & 0.111 & & & & -72.80 & -11.26 & 1350 & 37 & 49 & 10.39 & 140 & 30 & 37.71 & 54 \\
\hline 160 & 42.3 & & & & -30.30 & -4.80 & 1600 & 37 & 27 & 9.22 & 141 & 0 & 58.36 & 8 \\
\hline 161 & & & & & -64.00 & -10.18 & 3 & 37 & 32 & 20.31 & 140 & 38 & 8.59 & 416 \\
\hline 162 & & 6.444 & & & -61.10 & -9.52 & 7 & 37 & 36 & 57.89 & 140 & 33 & 38.41 & 268 \\
\hline 163 & & & & & -54.20 & -9.01 & & 37 & 24 & 25.00 & 140 & 51 & 11.34 & 509 \\
\hline 164 & & 1. 384 & & & -64.60 & -10.32 & & 37 & 37 & 27.50 & 140 & 33 & 50.23 & 324 \\
\hline 165 & & 0.322 & & & -51.60 & -8.64 & & 37 & 3 & 21.02 & 140 & 42 & 41.40 & 235 \\
\hline & & i Pref & sture & & & & & & & & & & & \\
\hline 166 & & & & & -55.80 & -9.43 & & 37 & 49 & 56.84 & 140 & 50 & 14.69 & 96 \\
\hline 167 & & & & & -55.70 & -9.33 & & 37 & 48 & 53.71 & 140 & 50 & 32.23 & 192 \\
\hline
\end{tabular}

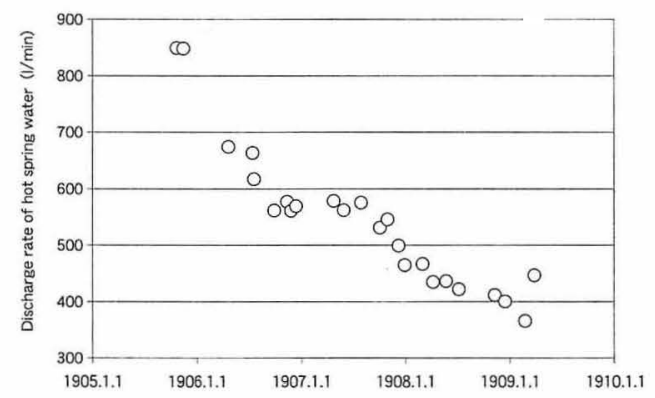

Fig. 2 Change of discharge rates of hot spring waters at Iwaki-Yumoto hot spring from 1905 to 1910

り, 地球内部にある地球創生時に閉じこめられた 熱, 放射性物質の崩壊による熱などが熱伝導など により地表に徐々に運び出されてくる現象のこと である。このことは, 常磐湯本温泉には火山性熱 源（例えば，中村·安藤，1953）の様な特別な熱 源を考える必要がないことを意味している。

阿武隈地域における温泉放熱量は, 常磐湯本温 泉からの熱量が際立って大きく，ついで大きな放 熱量を示す温泉はすべて火山フロントの近傍にあ る温泉である (地質調査所 (1980) を参照)。最大 の放熱量を示した常磐湯本温泉においても地殼熱 流量による加熱機構のみで説明が出来ることか
ら，阿武隈地域西部の火山フロントの近傍にある 温泉を除く全ての温泉の熱源は, 地殼熱流量によ る加熱機構のみで説明が可能であると考えられる。

\section{2. 温泉水の化学組成}

Fig. 3(a) 〜 3(c) に, 阿武隈地域の温泉水の塩化 物イオン $\left(\mathrm{Cl}^{-}\right)$濃度を, $100 \mathrm{mg} / \ell, 500 \mathrm{mg} / \ell$, $1,000 \mathrm{mg} / \ell$ および $5,000 \mathrm{mg} / \ell$ で, 硫酸イオン $\left(\mathrm{SO}_{4}{ }^{2-}\right)$ 濃度を, $100 \mathrm{mg} / \ell, 500 \mathrm{mg} / \ell$ および $1,000 \mathrm{mg} / \ell$ $\ell$, 重炭酸イオン $\left(\mathrm{HCO}_{3}^{-}{ }^{-}\right)$濃度を, $100 \mathrm{mg} / \ell, 250 \mathrm{mg} / \ell$ および $500 \mathrm{mg} / \ell$ で区分した 濃度分布図をそれぞれ示した。 $\mathrm{Cl}^{-}$濃度の最高濃 度の温泉はせんだん温泉 $(14,400 \mathrm{mg} / \ell$, 福島県双 葉町), $\mathrm{SO}_{4}{ }^{2-}$ 濃度の最高浱度は鵜の胛荘 (1450 $\mathrm{mg} / \ell$, 茨城県十王町) , $\mathrm{HCO}_{3}{ }^{-}$濃度の最高濃度は うねめ温泉 (825mg/l, 福島県郡山市)において, それぞれ観測されている。

Fig. 3(a) から， Cl- 濃度が $500 \mathrm{mg} / \ell$ を越える温 泉は, 内陸部にあるこおり温泉 $(1800 \mathrm{mg} / \ell$, 福 島県桑折町, 以下桑折温泉) 以外のすべての温泉 が海岸部に存在すること, $100 \mathrm{mg} / \ell$ を越える温泉 は海岸部以外に, 内陸部の郡山市西部および茨城 県大子町に存在していることがわかる。また Fig. 


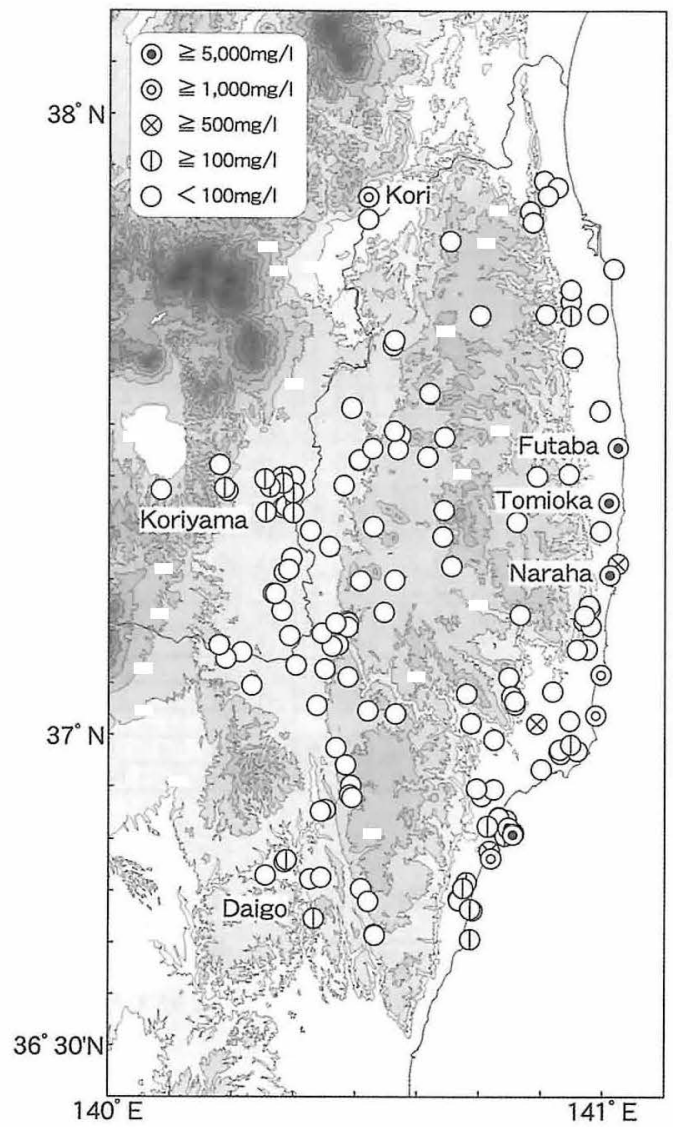

Fig. 3(a) Distribution map of chloride ion concentrations of hot spring waters taken from Abukuma area

3(b) から， $\mathrm{SO}_{4}^{2-}$ 濃度が $1,000 \mathrm{mg} / \ell$ を越える温泉 は, 海岸部の茨城県北茨城市に 2 温泉, 内陸部に 桑折温泉がそれでれ存在すること, $100 \mathrm{mg} / \ell$ を越 える温泉は海岸部以外に, 内陸部の郡山市西部お よび大子町に存在していることがわかる。Fig. 3(a) と, Fig. 3(b) を比較すると, 海岸部, 内陸部 の桑折町, 郡山市西部拉よび大子町において $\mathrm{Cl}^{-}$ 濃度, $\mathrm{SO}_{4}{ }^{2-}$ 濃度とも高くなっており，雨者の高 濃度地域が概略一致していることがわかる。ただ し, 海岸部における $\mathrm{Cl}^{-}$濃度と $\mathrm{SO}_{4}{ }^{2-}$ 濃度の分布を 詳細に見ると, $\mathrm{Cl}^{-}$濃度の高い部分が福島県いわ き市から双葉郡など, より北方にあるのに対し， $\mathrm{SO}_{4}{ }^{2-}$ 濃度の高い部分は茨城県北茨城市など, より 南方にあるなど, 必ずしも完全に一致しているわ けではないこともわかる。

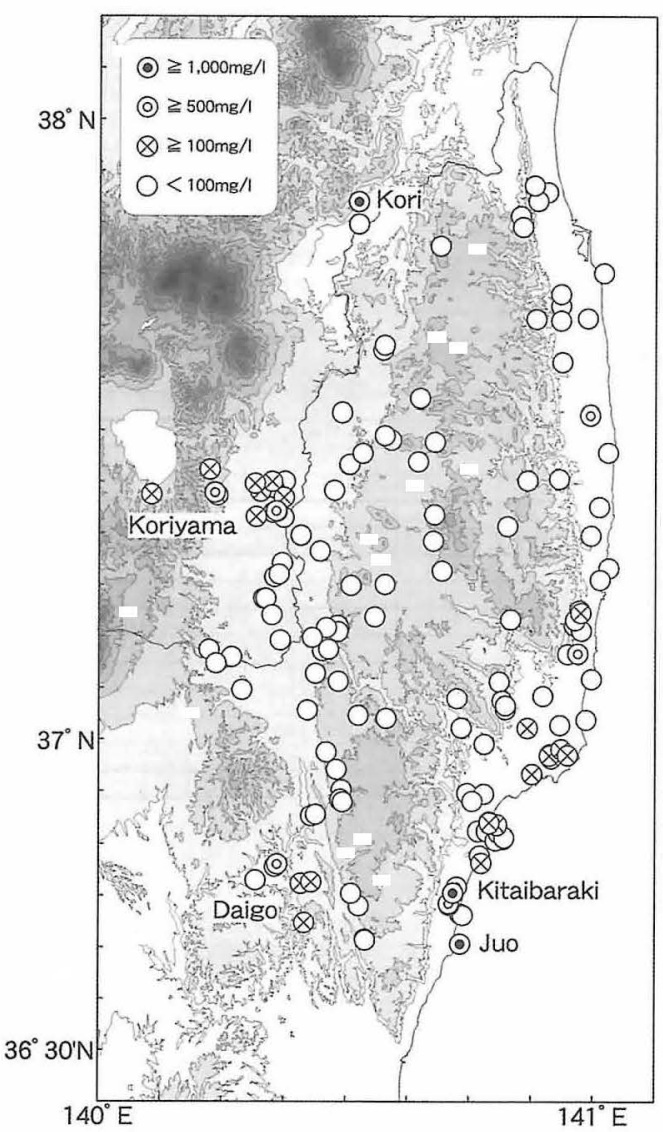

Fig. 3(b) Distribution map of sulfate ion concentrations of hot spring waters taken from Abukuma area

一方, Fig. 3(c) から, $\mathrm{HCO}_{3}{ }^{-}$濃度が $500 \mathrm{mg} / \ell$ を越える温泉は, 海岸部の茨城県高萩市および北 茨城市に存在すること, $100 \mathrm{mg} / \ell$ を越える温泉 は, 阿武隈高原部以外の場所に存在していること がわかる。また Fig. 3(c) を, Fig. 3(a) および Fig. 3(b) と比較すると, $\mathrm{HCO}_{3}{ }^{-}$濃度と $\mathrm{Cl}^{-}$濃度および $\mathrm{SO}_{4}^{2-}$ 濃度が高濃度である地域が一致しないこと がわかる。

Fig. 4(a) 〜 4(c) に, 阿武隈地域の温泉水の $\mathrm{Cl}^{-}$; $\mathrm{SO}_{4}{ }^{2-}$ および $\mathrm{HCO}_{3}{ }^{-}$各濃度と, 試料採取標高の関 係を示した。坑井深度が明らかな場合は, 坑底か ら温泉水が湧出していると仮定して, (試料採取標 高- 坑井深度)の位置に $\mathrm{Cl}^{-}, \mathrm{SO}_{4}{ }^{2-}$ および $\mathrm{HCO}_{3}{ }^{-}$濃 度をそれぞれプロットした。

Fig. 4 Fig. 9 の凡例は, 温泉の化学 - 同位体 


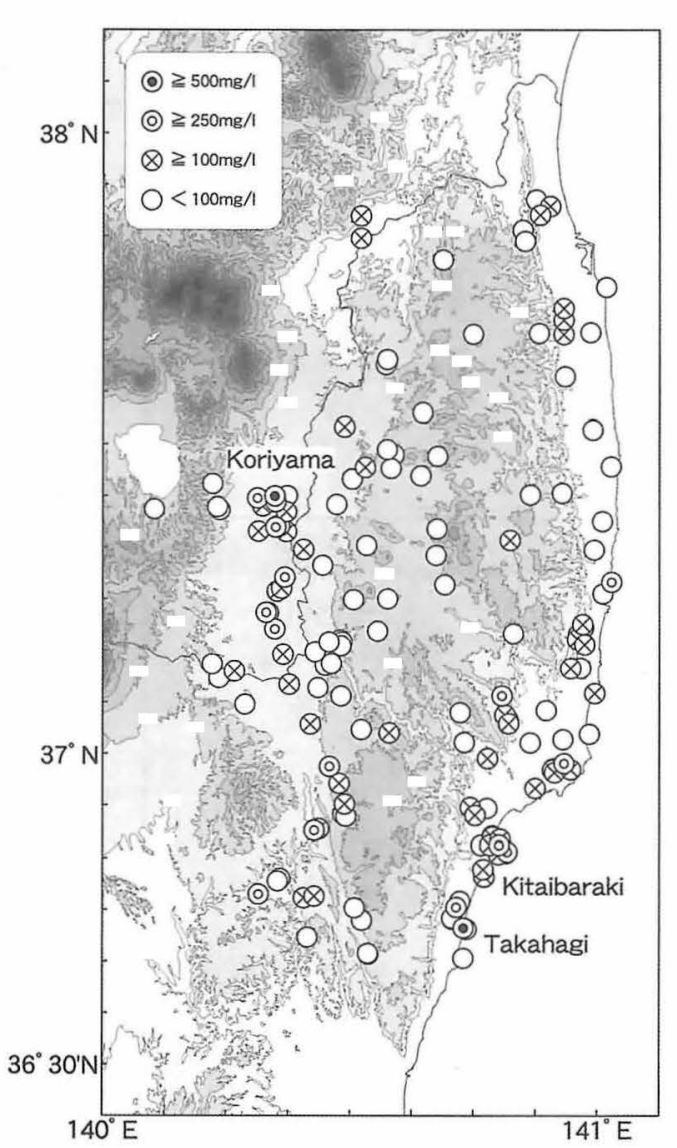

Fig. 3(c) Distribution map of bicarbonate ion concentrations of hot spring waters taken from Abukuma area

組成と地域的な分布との関連を明確に表示するこ とを目的として，以下のように区分した。

（1）塩化物イオン濃度が $5,000 \mathrm{mg} / \ell$ 以上ある高 塩濃度の温泉。すべての温泉が(2)の地域の海 岸部にある。

（2）試料採取標高が $200 \mathrm{~m}$ 以下の温泉。阿武隈高 原の東側の海岸部と, 阿武隈高原の南西側で八 溝山地との間（大子地域）に存在する。

（3）試料採取標高が $200 \mathrm{~m}$ 以上の温泉。阿武隈高 原地域と, 阿武隈高原の西側で背梁山脈との間 (阿武德川西岸地域)に存在する。阿武隈高原地 域の面積的割合が他地域と比べ大きいので, 便 宜的に東経 140.5 度を境に東側と西側に区分した。

(2)と（3）により，温泉は東から西へ順に，(a) 海岸部, (b) 阿武隈高原（東側）地域，(c) 阿武

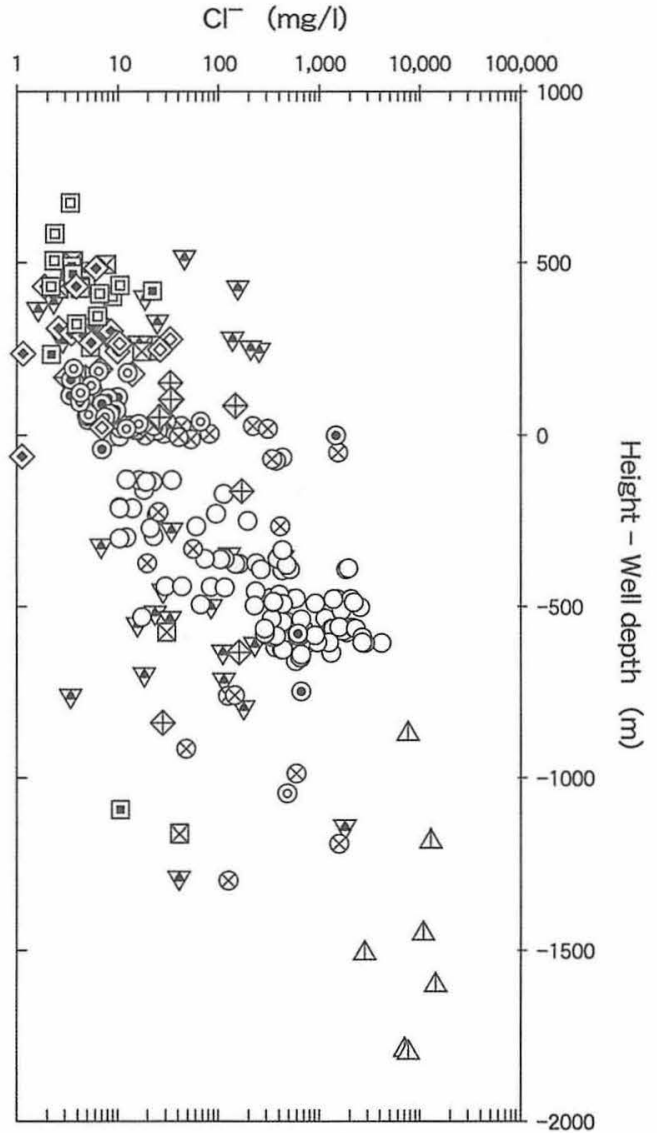

Fig. 4(a) Vertical variation of chloride ion concentrations of hot spring waters taken from Abukuma area

$\triangle:$ Hot spring waters which contain higher than $5,000 \mathrm{mg} / 1$ chloride ion All hot springs in this category are in coastal area

$\bigcirc$ : Hot springs in coastal area

Sampling altitude $<200 \mathrm{~m}$, Longitude $\geqq 140.625^{\circ} \mathrm{E}$ Latitude $<37^{\circ} \mathrm{N}(\otimes), 37^{\circ} \mathrm{N} \leqq$ Latitude $<37.4^{\circ}$ $\mathrm{N}(\odot)$, Latitude $\geqq 37.4^{\circ} \mathrm{N}(\odot)$

$\oplus$ : Hot springs in Daigo area

Sampling altitude $<200 \mathrm{~m}$, Longitude $<140.625^{\circ}$ E, Latitude $<37^{\circ} \mathrm{N}$

$\square$ : Hot springs in the eastern part of the Abukuma highlands

Sampling altitude $>200 \mathrm{~m}$, Longitude $\geqq 140.5^{\circ} \mathrm{E}$ Latitude $<37^{\circ} \mathrm{N}(\otimes), 37^{\circ} \mathrm{N} \leqq$ Latitude $<37.4^{\circ} \mathrm{N}$ (回), Latitude $\geqq 37.4^{\circ} \mathrm{N}$ (回)

$\diamond:$ Hot springs in the western part of the Abukuma highlands

Sampling altitude $>200 \mathrm{~m}$, Longitude $<140.5^{\circ} \mathrm{E}$ $37^{\circ} \mathrm{N} \leqq$ Latitude $<37.4^{\circ} \mathrm{N}(\diamond)$, Latitude $\geqq 37.4^{\circ} \mathrm{N}(\diamond)$

$\otimes:$ Hot springs in the western side of the Abukuma River Sampling altitude $>200 \mathrm{~m}$

Longitude $<140.4^{\circ} \mathrm{E}$ and Latitude $\geqq 37^{\circ} \mathrm{N}$, or Longitude $<140.6^{\circ} \mathrm{E}$ and Latitude $\geqq 37.8^{\circ} \mathrm{N}$

$\bigcirc$ : Iwaki-Yomoto hot spring (Nakamura and Ando, 1953) 


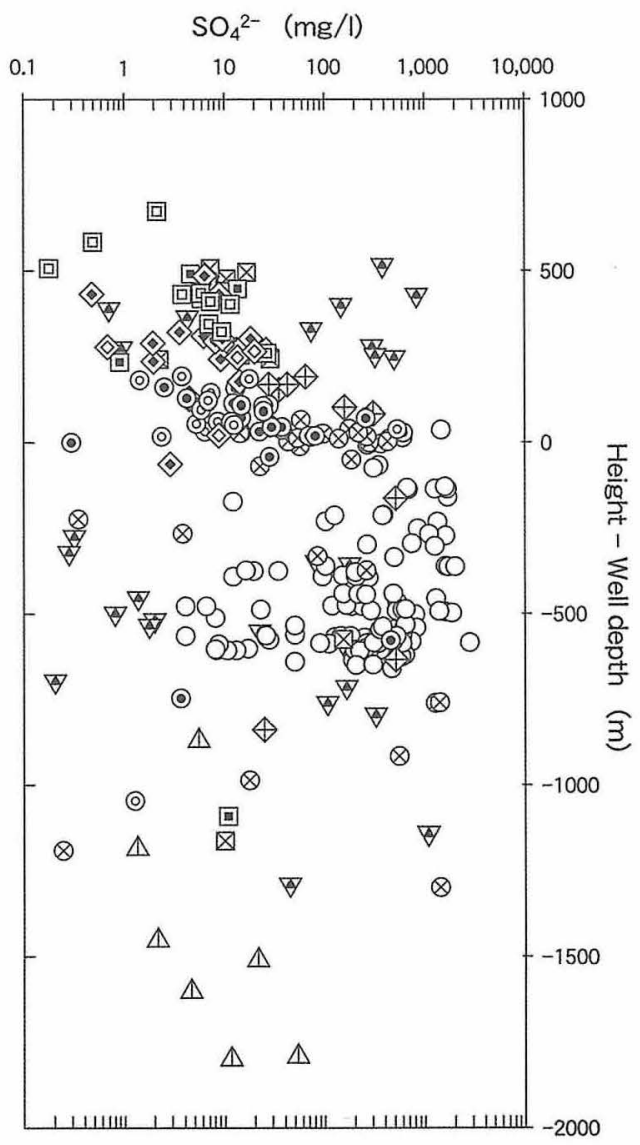

Fig. 4(b) Vertical variation of sulfate ion concentrations of hot spring waters taken from Abukuma area Same legends with Figure 4(a).

隈高原（西側）地域，および (d) 阿武隈川西岸 地域に区分される。大子地域は (c) の阿武隈高 原（西側）地域の最南部に位置する。

（4）温泉の化学 ·同位体組成の南北方向の違いを 示すため, (a) 海岸部, (b) 阿武隈高原（東側） 地域, および (c) 阿武隈高原（西側）地域の温 泉を, 北緯 37 度以南, 北緯 37-37.4 度および北 緯 37.4 度以北に区分した。大子地域の温泉は北 緯 37 度以南に区分された。

(1)〜 (4)により, 研究地域の温泉は 11 の地域 に区分された。表示する印の詳細は Fig. 4(a) の説 明に書き込んである。

また, Fig. 4(a)〜 4(c) には, 中村·安藤（1953） が示した常磐湯本温泉の温泉湧出深度と $\mathrm{Cl}^{-}$,

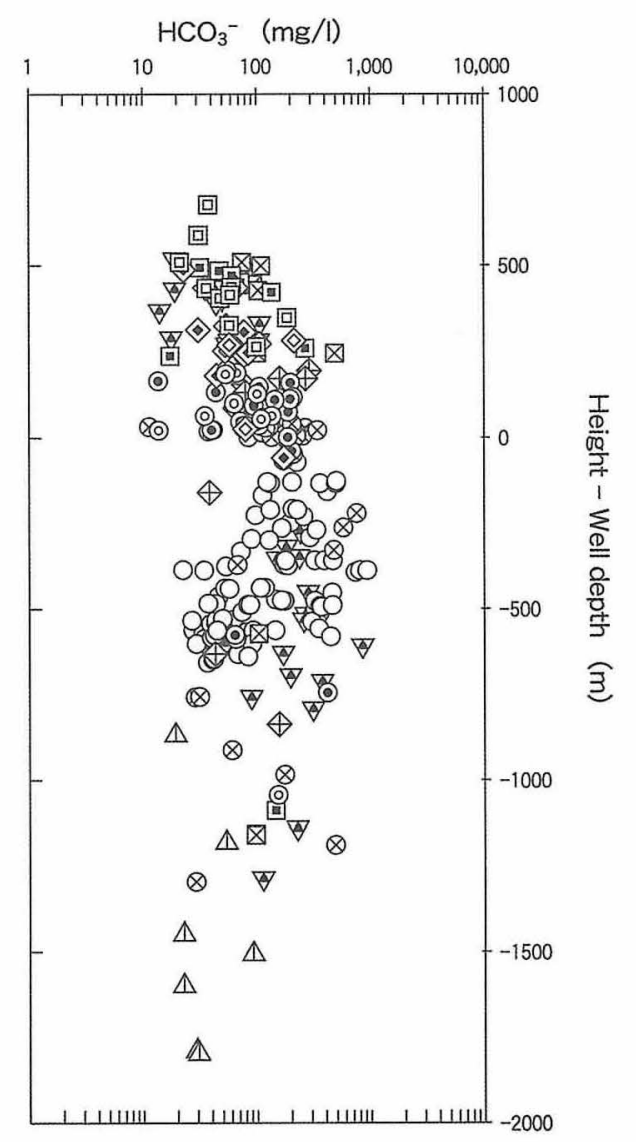

Fig. 4(c) Vertical variation of bicarbonate ion concentrations of hot spring waters taken from Abukuma area Same legends with Figure 4(a).

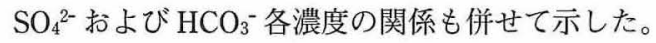
Fig. 4(a) から， $\mathrm{Cl}^{-}$濃度は濃度幅があるものの深 度とともに増加する傾向があることがわかる。ま た, Fig. 4(b) から, $\mathrm{SO}_{4}^{2-}$ 濃度は-1500 $\mathrm{m}$ 以深では 最高でも $50 \mathrm{mg} / \ell$ 程度と全般的に低濃度である

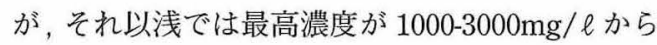
非常に低濃度の部分まで非常に濃度幅が広い状態 が最上部まで続いていることがわかる。一方, Fig. 4(c) から, $\mathrm{HCO}_{3}{ }^{-}$濃度は-500 0m 付近で濃 度が最高 $800 \mathrm{mg} / \ell$ と高く, $0 \mathrm{~m}$ 以浅では深度とと もに濃度が徐々に増加し， $-500 \mathrm{~m}$ 以深では濃度が 徐々に低下する傾向があることがわかる。このよ うな濃度変化のため, 阿武隈地域では, 最深部に $\mathrm{Cl}$ 型，その上部に $\mathrm{Cl}-\mathrm{SO}_{4}$ 型あるいは $\mathrm{Cl}-\mathrm{HCO}_{3}$ 型， 
その上部に $\mathrm{Cl}_{-} \mathrm{SO}_{4}-\mathrm{HCO}_{3}$ 型など $\mathrm{Cl}, \mathrm{SO}_{4}, \mathrm{HCO}_{3}$ 三者が関連する泉質, 最上部に $\mathrm{SO}_{4}-\mathrm{HCO}_{3}$ 型, $\mathrm{HCO}_{3}-\mathrm{SO}_{4}$ 型あるいは $\mathrm{SO}_{4}$ 型という順に, 温泉の 泉質が変化していることになる。中村 (1962) は, 常磐湯本温泉では, 常磐炭田の坑内深部から $\mathrm{Cl}$ 型および $\mathrm{Cl}_{-}-\mathrm{SO}_{4}$ 型, 一部に $\mathrm{Cl}-\mathrm{HCO}_{3}$ 型温泉が, 古 洞から $\mathrm{Cl}-\mathrm{HCO}_{3}-\mathrm{SO}_{4}$ 型温泉水が, 浅部坑道から $\mathrm{HCO}_{3}-\mathrm{SO}_{4}$ 型, 一部に $\mathrm{SO}_{4}$ 型地下水が, それぞれ 湧出することを示した。深度に対する泉質变化の 順序が Fig. 4(a)～4(c) から示唆される泉質変化の 順序と全く同じであることがわかる。

Fig. 5 に, 阿武隈地域の温泉水の $\mathrm{Cl}^{-}$濃度と $\mathrm{SO}_{4}{ }^{2-}$ 濃度の関係を示した。Fig. 3(a) および Fig. 3(b)に 示した両濃度の地理的分布からも推定されたよう に, $\mathrm{Cl}^{-}$濃度と $\mathrm{SO}_{4}{ }^{2-}$ 濃度との間には 2 つの関係, すなわち (1)濃度幅は広いが $\mathrm{Cl}^{-}$濃度と $\mathrm{SO}_{4}{ }^{2-}$ 濃度 との間に正の相関関係がある温泉が存在するこ と, (2)海岸部では $\mathrm{Cl}^{-}$濃度の高さに比べ, $\mathrm{SO}_{4}{ }^{2-}$ 濃度が著しく低い温泉が存在することが見て取れ る。Jenden and Gieskes (1984) は, 海洋堆積物中 の間隙水の化学組成を報告した。 $\mathrm{Cl}^{-}$濃度が海水 程度であるのに対し, $\mathrm{SO}_{4}{ }^{2-}$ 濃度の多くは分析限 界以下であった。加藤・梶原（1986）および加藤 ほか（2000）は, 新潟から秋田地域に掘削された 石油井から産出する油田鹹水の化学組成を報告し た。Jenden and Gieskes (1984) と同様に, $\mathrm{Cl}^{-}$濃 度が海水程度であるのに対し, $\mathrm{SO}_{4}{ }^{2-}$ 濃度は高々 $100 \mathrm{mg} / \ell$ 程度, 多くは分析限界以下であった。こ れらのことは, $\mathrm{Cl}^{-}$濃度が高く, $\mathrm{SO}_{4}{ }^{2-}$ 濃度が著し く低い温泉水は, 間隙水あるいは油田醎水と類似 した性質を持つ，地層中に封入されている塩水を 起源としている可能性を示唆している。

また Fig. $5 て ゙, \mathrm{Cl}^{-}$濃度, $\mathrm{SO}_{4}^{2-}$ 濃度とも $1000 \mathrm{mg} /$ もを越える位置にプロットされているのは桑折温 泉のみである。泉質は $\mathrm{Na}-\mathrm{Cl}^{-} \mathrm{SO}_{4}$ 型であり, 桑折 町がいわゆるグリーンタフ地域（例えば，日本の 地質「東北地方」編集委員会，1989，197p.）に位 置していることを考えると，本温泉は，地下水が 地層中の塩化物塩, 硫酸塩鉱物を溶出させること により形成される温泉 (Matsubaya et al., 1973)，い

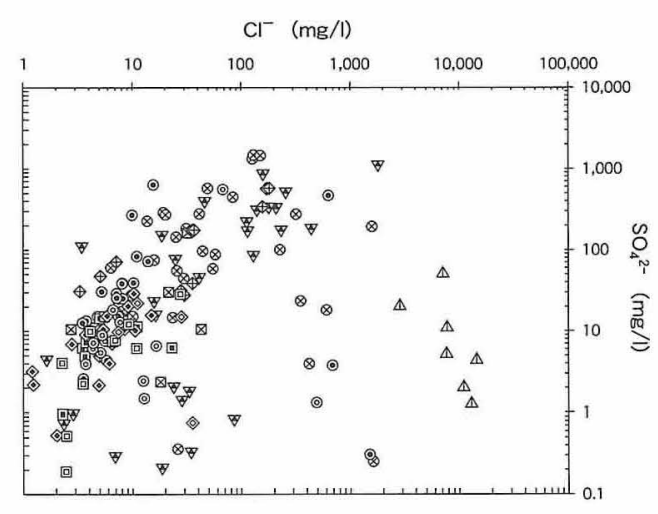

Fig. 5 The relation between chloride and sulfate ion concentrations of hot spring waters taken from Abukuma area Same legends with Figure 4(a).

わゆるグリーンタフ型温泉 (Sakai and Matsubaya, 1974）である可能性があると考学られる。Fig. 6 に, Sakai and Matsubaya (1974) と松葉谷 (1981) が典型的なグリーンタフ型温泉であるとした大鰥 温泉（中村, 1962）, 鳥取周辺の温泉（比留川, 1981）および青函隧道坑内水（Mizukami et al.,

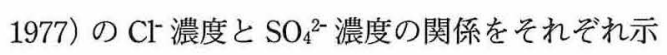
した。グリーンタフ型温泉に分類されている温泉 は, $\mathrm{SO}_{4}{ }^{2-}$ 濃度の最高濃度は $1000 \mathrm{mg} / \ell$ 程度であ るが, $\mathrm{Cl}^{-}$濃度は $100 \mathrm{mg} / \ell$ から $15,000 \mathrm{mg} / \ell$ まで 大きな濃度範囲に分布すること, すなわち $\mathrm{Cl}^{-} \mathrm{SO}_{4}$ 型のみならず, $\mathrm{Cl}$ 型から $\mathrm{SO}_{4}$ 型まで幅広い泉質に 分布することがわかる。中村 (1962) は, 大䱮温 泉では $\mathrm{Ca}-\mathrm{SO}_{4}$ で特徴づけられる温泉系と, Na-Cl$\mathrm{HCO}_{3}$ で特徴づけられる温泉系が混合して形成さ れていると考えている。

Fig. 6 には, Fig. 5 で示した阿武隈地域温泉水 および常磐湯本温泉水 (中村, 1962 ) $の \mathrm{Cl}^{-}$濃度 と $\mathrm{SO}_{4}{ }^{2-}$ 濃度の関係を併せて示した。阿武隈川の西 岸地域（いわゆるグリーンタフ地域）に分布する 温泉の $\mathrm{Cl}^{-}$濃度と $\mathrm{SO}_{4}^{2-}$ 濃度の関係と, その東部, すなわち阿武隈地域の海岸部 (Fig. 6 の $\otimes$, ○お よび○印）と，阿武隈高原と八溝山地に挟まれた 大子地域にある非グリーンタフ地域の海成層から 得られる温泉（Fig. 6 の印）の $\mathrm{Cl}^{-}$濃度と $\mathrm{SO}_{4}{ }^{2-}$ 濃度の関係とは, 非常に類似して抢り, 泉質的に 


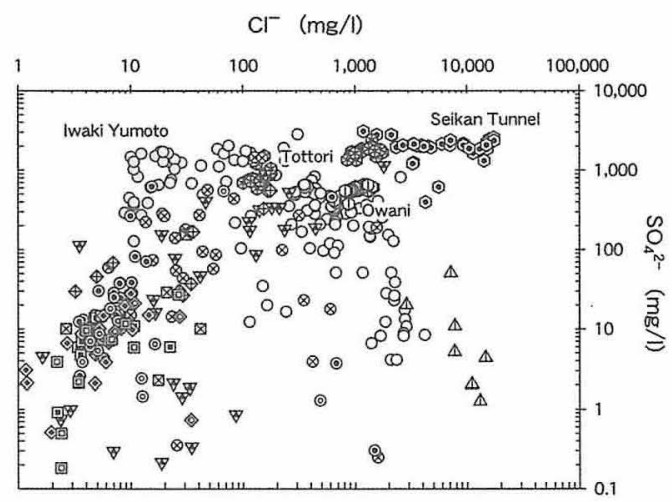

Fig. 6 The relation between chloride and sulfate ion concentrations of hot spring waters taken from Joban-Yomoto, Seikan Tunnel, Owani and Tottori hot spring

$\bigcirc$ : Iwaki-Yumoto hot spring, (-): Brine from Seikan Tunnel, $(1)$ : Owani hot spring, $\circledast$ : Hot springs in Tottori area Other legends are same with Figure 4(a)

両者を区別することが出来ないことがわかる。こ こから, $\mathrm{Cl}^{-}$濃度と $\mathrm{SO}_{4}{ }^{2-}$ 濃度の両方が高濃度の温 泉は, グリーンタフ型温泉と同様の形成機構, す なわち地下水が地層中の塩化物塩, 硫酸塩鉱物を 溶出させることにより形成される温泉である可能 性を示唆している。ただ, Fig. 4(a) 図に示したよ うに, $\mathrm{Cl}^{-}$濃度は深度とともに一方的に増加する 傾向があり, 温泉水中の塩化物イオンを供給して いるのが，ある深度までは塩化物塩の地下水によ る溶出, ある深度からは堆積岩中に封入されてい る間隙水，あるいは油田咸水に類似の性質を持つ 塩水の流出というような区別を考えるより，堆積 岩中に封入されている塩水が地下水により様々な 割合に希勫されたものである可能性についても考 慮すべきであると考える。

\section{3，温泉水の水素・酸素同位体比}

Fig. 7 に, 阿武隈地域の温泉水の水素同位体比 $(\delta \mathrm{D}$ 值) の分布を示した。 $\delta \mathrm{D}$ 值の最大值は海岸 部にある五浦温泉 (-24\%, 茨城県北茨城市), 最 小值は阿武隈川の西岸地域にある野田温泉 $(-73$ \%，福島県伊達町）において，それぞれ観測され ている。Fig. 7 から，(1)海岸部に $\delta \mathrm{D}$ 值が大きな

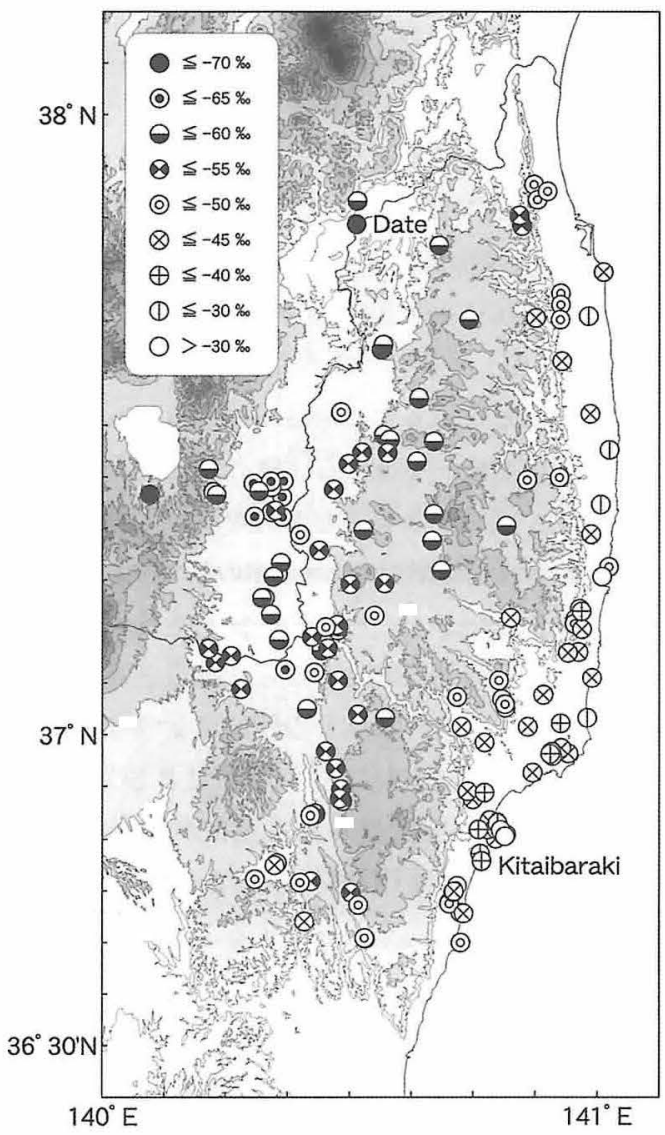

Fig. 7 Distribution map of hydrogen isotopic ratios of hot spring waters taken from Abukuma area

温泉が多いこと，すなおち海岸部の温泉の形成に は天水以外に, 例えば海水のような大きな水素同 位体比を持つ水が関与していること, および(2) 阿武隈川の西岸地域の温泉の $\delta \mathrm{D}$ 值が他の地域に 比べ非常に小さいことがわかる。阿武隈川の西岸 地域の温泉は, 地形から考えて涵養域が阿武隈高 原側ではなく，袷梁山脈側であることが推定さ れ，内陸度や涵養標高を考えてもより小さな同位 体比を持つ天水が供給される可能性が十分考えら れる。実際, Mizota and Kusakabe (1994) の Fig. 2 から, 蓨梁山脈側の地下水が $10 ２ 0 \%$ も水素同 位体比が小さいことが見て取れる。

Fig. 8(a) および Fig. 8(b) に, 阿武隈地域の温泉 水の $\delta \mathrm{D}$ 值と酸素同位体比 $\left({ }^{18} \mathrm{O}\right.$ 值) の関係を示 
した。Fig. 8(b)には，塩化物イオン濃度が $500 \mathrm{mg}$ / $\ell$ 以下の温泉のみ示した。Fig. 7 と同様に, (1)塩 化物イオン濃度が概略 $5000 \mathrm{mg} / \ell$ 以上の温泉のみ が非常に大きな $\delta \mathrm{D}$ 值および $\delta^{18} \mathrm{O}$ 值を持つこと， および(2)例えば桑折温泉など, 阿武隈川の西岸 地域の温泉の $\delta \mathrm{D}$ 值打よび ${ }^{18} \mathrm{O}$ 值は非常に小さい という涵養域の違いを反映した現象が見られるこ とがわかる。

Fig. 8(a) で, $\delta \mathrm{D}$ 值および $\delta^{18} \mathrm{O}$ 值が他の地域と 著しく異なり, 非常に大きな值を示すのは, 茨城 県北茨城市にある 3 温泉 (Table 1 に○で表示, 以 下北茨城温泉群）と, 福島県双葉郡にある 3 温泉

(Table 1 に○で表示, 以下, 双葉温泉群) であ る。北茨城温泉群は $\delta \mathrm{D}$ 值と $\delta^{18} \mathrm{O}$ 值との間に良い 相関が見られる。北茨城市内の海岸近傍にある $\mathrm{Cl}^{-}$濃度が $500 \mathrm{mg} / \ell$ 程度以上ある 7 温泉*4 (Fig. 8(a) に灰色印で, Table 1 に○で，それぞれ表示) の $\delta \mathrm{D}$ 值と $\delta^{18} \mathrm{O}$ 值を用いて両者の関係を求めると,

$$
\delta \mathrm{D}=5.35 \times \delta^{18} \mathrm{O}-4.6\left(\mathrm{R}^{2}=0.98\right)
$$

という, 非常に良い相関が見られる。北茨城市北 隣の福島県いわき市にある $\mathrm{Cl}^{-}$濃度が $500 \mathrm{mg} /$ ～以 上ある 3 温泉 (Table 1 に○で表 示, 以下, いわき温泉群）も, 上 述の回帰直線に近い位置に $\delta \mathrm{D}$ 值 と $\delta^{18} \mathrm{O}$ 值とがプロットされること がわかる。一方, 双葉温泉群の内, 楢葉, 双葉雨温泉の $\delta \mathrm{D}$ 值と $\delta^{18} \mathrm{O}$ 値とは, 北茨城温泉群から求めた 回帰直線のごく近傍にプロットさ れるが, 富岡温泉は, $\delta^{18} \mathrm{O}$ 值が相 対的に大きな位置にプロットされ ることがわかる (Fig. 8(a))。双葉 温泉群には, 北茨城一いわき温泉 群とは性質が異なる温泉水が存在 している可能性を示唆していると 考えられる。

$\mathrm{Cl}^{-}$濃度が高い温泉のうち桑折 温泉は, $\delta \mathrm{D}$ 值が-60\%。, $\delta^{18} \mathrm{O}$ 值が-
$10.2 \%$ と，いずれの值も非常に小さく，周辺部の $\mathrm{Cl}^{-}$濃度が $500 \mathrm{mg} / \ell$ 以下の低塩濃度の温泉と同 様, meteoric water lineの近傍にプロットされるこ とがわかる (Fig. 8(a))。Matsubaya et al. (1973) が 示した，日本海側に多く見られ， $\mathrm{Cl}^{-}$濃度は高い が，その安定同位体組成が天水と類似していると いう,グリーンタフ型温泉 (Sakai and Matsubaya, 1974）と共通した特徴を持つことが水素・酸度同 位体比からも推定される。

Fig. 8(b) から, $\mathrm{Cl}^{-}$濃度が $500 \mathrm{mg} / \ell$ 以下の温泉 は, その大部分が $\delta \mathrm{D}$ 值と $\delta^{18} \mathrm{O}$ 值の比が約 8 の相 関線の近傍に位置していることがわかる。各温泉 の $\mathrm{d}$ 值（ $\delta \mathrm{D}$ 值 $-8 \times \delta^{18} \mathrm{O}$ 值）は, 最大値 23 , 最小 值 14 , 平均值 17.4 である。この值は, 関東平野 の河川水の $\mathrm{d}$ 值（大部分 $10 \sim 12$, 稲村·安原, 2003) と, 日本海側の冬季の降水の平均の $\mathrm{d}$ 值 (26, 松葉谷, 1981) との中間的な值である。 NEDO（1991）は，阿武隈地域の西にある磐梯地 域の河川水の $\delta \mathrm{D}$ 值と $\delta^{18} \mathrm{O}$ 值を報告している。計 算される $\mathrm{d}$ 值は, 最大值 29 , 最小值 7 と, やや分 布範囲が広いが, 平均值は 18.8 であり, 今回阿武

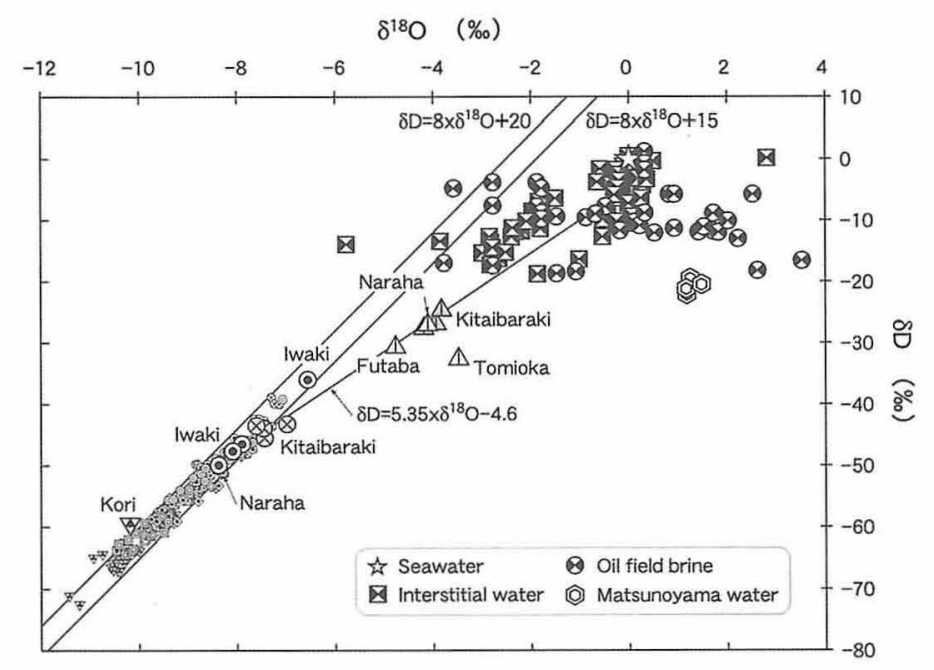

Fig. 8(a) The relation between hydrogen and oxygen isotopic ratios of hot spring waters taken from Abukuma area

Same legends with Fig. 4(a). A regression line is calculated from seven isotopic data of hot springs marked gray and "Kitaibaraki" in the diagram.

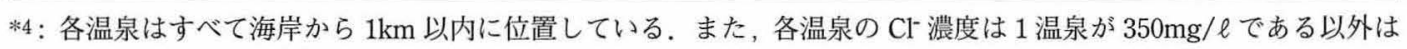
すべて $500 \mathrm{mg} / \ell$ 以上. 


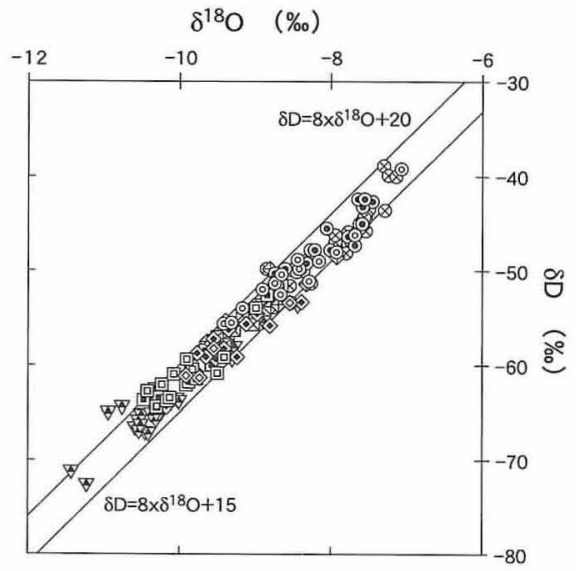

Fig. 8(b) The relation between hydrogen and oxygen isotopic ratios of hot spring waters taken from Abukuma area, which contain less than $500 \mathrm{mg} / 1$ chloride ion.

Same legends with Figure 4(a).

隈地域の温泉水から得られた $\mathrm{d}$ 值とほぼ同等であ る。ここから, $\mathrm{Cl}^{-}$濃度が低い温泉の水の起源は 基本的には天水であると考元られる。

Fig. 9(a) および Fig. 9(b) に, 阿武隈地域の温泉 水の $\mathrm{Cl}^{-}$濃度と， $\delta \mathrm{D}$ 值， $\delta^{18} \mathrm{O}$ 值それぞれの関係 を示した。Fig. 9(a)，9(b)には, 海洋堆積物中の 間隙水 (Jenden and Gieskes, 1984)，油田蒧水 (加 藤・梶原，1986；加藤ほか，2000）および松之山

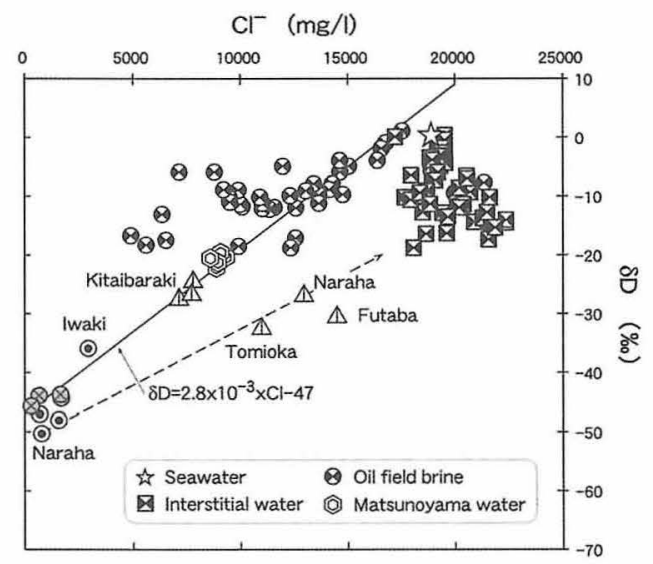

Fig. 9(a) The relation between hydrogen isotpic ratios and chloride ion concentrations of hot spring waters taken from Abukuma area Same legends with Figure 8(a). A regression line is calculated from seven isotopic data of hot springs marked gray and "Kitaibaraki" in the diagram.
温泉水（渡部ほか，1996）の $\mathrm{Cl}^{-}$濃度と， $\delta \mathrm{D}$ 值， $\delta^{18} \mathrm{O}$ 值それぞれの関係も同時に示した。Fig. 8 で 良い相関が見られた北茨城温泉群では, Fig. 9(a)， 9(b)でもやはり良い相関が見られる。Fig. 8 と同 様に, 北茨城市内の $\mathrm{Cl}^{-}$濃度が $500 \mathrm{mg} / \ell$ *4 程度以 上ある 7 温泉（Fig. 9(a)，9(b) に灰色印で表示) の $\mathrm{Cl}^{-}$濃度と, $\delta \mathrm{D}$ 值, $\delta^{18} \mathrm{O}$ 值を用いて関係を求 めると，

$$
\begin{aligned}
& \delta \mathrm{D}=2.8 \times 10^{-3} \times \mathrm{Cl}-47.0\left(\mathrm{R}^{2}=0.98\right) \\
& \delta^{18} \mathrm{O}=5.2 \times 10^{-4} \times \mathrm{Cl}-7.9\left(\mathrm{R}^{2}=0.99\right)
\end{aligned}
$$

という，非常に良い相関が見られる。回帰直線の $\mathrm{Cl}^{-}$濃度が高い方向への外挿は, 加藤·梶原（1986） および加藤ほか (2000) が示した油田虡水の部分 を通っている。また,北隣のいわき温泉群の $\mathrm{Cl}^{-}$濃 度と, $\delta \mathrm{D}$ 值， $\delta^{18} \mathrm{O}$ 值それぞれの関係も，北茨城 温泉群から得られる回帰直線の近傍に位置してい る (Fig. 9(a), 9(b))。

一方, 双葉温泉群の $\mathrm{Cl}^{-}$濃度と, $\delta \mathrm{D}$ 值, $\delta^{18} \mathrm{O}$ 值との関係からは，北茨城一いわき温泉群で広範 囲に見られるような, 海洋堆積物間隙水あるいは 油田咸水的な $\mathrm{Cl}^{-}$濃度が高い部分と, 天水的な $\mathrm{Cl}^{-}$ 濃度が低い部分の混合というような傾向がみられ ない。各温泉ごとに $\mathrm{Cl}^{-}$濃度が高い部分の化学的・ 同位体的性質が異なっていると考えられる。これ

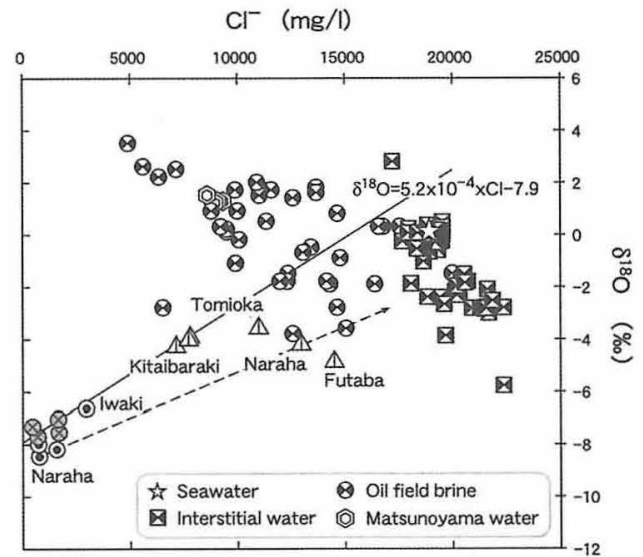

Fig. 9(b) The relation between oxygen isotpic ratios and chloride ion concentrations of hot spring waters taken from Abukuma area

Same legends with Figure 8(a). A regression line is calculated from seven isotopic data of hot springs marked gray and "Kitaibaraki" in the diagram 
は, 双葉温泉群は, 北茨城一いわき温泉群より相 互に化学的・同位体的に孤立している可能性, す なはち相互の温泉貯留層の連続性がそしいことを 示唆していると考えられる。双葉温泉群近傍の $\mathrm{Cl}^{-}$濃度が低い温泉 (ならは天神岬温泉水) を起点 として双葉温泉群の各温泉水と結んだ外挿方向を 見ると, 楢葉, 双葉両温泉は, $\mathrm{Cl}^{-}$濃度と $\delta \mathrm{D}$ 值, $\mathrm{Cl}^{-}$濃度と $\delta^{18} \mathrm{O}$ 值, 両者とも海洋堆積物のコア試 料から得られた間隙水の方向となっている。また 詳細に見ると, 双葉温泉の方がより $\mathrm{Cl}^{-}$濃度が高 $<, \delta \mathrm{D}$ 值, $\delta^{18} \mathrm{O}$ 值とも小さい間隙水の方向に なっている (Fig. 9(a)，9(b))。一方, 富岡温泉に ついては,その外挿方向は $\mathrm{Cl}^{-}$濃度と $\delta \mathrm{D}$ 值から推 定される端成分と, $\mathrm{Cl}^{-}$濃度と $\delta^{18} \mathrm{O}$ 值から推定さ れる端成分が若干異なっている。Fig. 8 に示した ように, $\delta \mathrm{D}$ 値と $\delta^{18} \mathrm{O}$ 值との関係も他の 2 温泉と 異なっている。原因については不明である。今後 の検討課題としたい。

\section{V. 結 論}

茨城県北東部, 福島県東部および宮城県南東部 にまたがる阿武隈地域の 167 ヶ所から温泉水試料 を採取し, その化学組成扣よび水の水素・酸素同 位体比の分析および解析を行った。その結果, 以 下のことが明らかになった。

(1) $25^{\circ} \mathrm{C}$ 以上の温泉の大部分は, 阿武隈花崗岩 類, 阿武隈変成岩などが分布する阿武隈地域の 主要部以外の地域, すなわち (a) 主に第三紀の 海成層からなる海岸部, (b) 阿武隈高原と八溝 山地の間 (大子地域), および (c) 阿武隈川の西 岸地域に分布している。本地域内で最大の温泉 放熱量が報告されている常磐湯本温泉において も自然状態の温泉放熱量の熱階級はIII であると 推定でき, 地殻熱流量による加熱機構以外の特 別な熱源を考える必要はないと考えられること から, 阿武隈川の西岸地域の火山フロント近傍 にある温泉を除く, 阿武隈地域の全ての温泉の 熱源は, 地殼熱流量による加熱機構で説明可能 であると考えられる。
（2）阿武隈地域の温泉水の泉質は，最深部に $\mathrm{Cl}$ 型，その上部に $\mathrm{Cl}_{-} \mathrm{SO}_{4}$ 型あるいは $\mathrm{Cl}-\mathrm{HCO}_{3}$ 型, その上部に $\mathrm{Cl}-\mathrm{SO}_{4}-\mathrm{HCO}_{3}$ 型など, $\mathrm{Cl}, \mathrm{SO}_{4}, \mathrm{HCO}_{3}$ 三者が関連する泉質, 最上部に $\mathrm{SO}_{4}-\mathrm{HCO}_{3}$ 型, $\mathrm{HCO}_{3}-\mathrm{SO}_{4}$ 型あるいは $\mathrm{SO}_{4}$ 型という順に垂直的 に変化している。

（3）阿武隈地域の温泉は, $\mathrm{Cl}^{-}$濃度と $\mathrm{SO}_{4}^{2-}$ 濃度と の関係から, (a) $\mathrm{Cl}^{-}$濃度と $\mathrm{SO}_{4}{ }^{2-}$ 濃度との間に正 の相関関係がある温泉, および (b) 海岸部の $\mathrm{Cl}^{-}$ 濃度の高さに比べ, $\mathrm{SO}_{4}{ }^{2-}$ 濃度が著しく低い温 泉の 2 種類に区分できることがわかった。前者 は地下水が地層中の塩化物塩, 硫酸塩鉱物を溶 出させることにより形成されるグリーンタフ型 温泉あるいは類似の形成機構を持つ温泉である 可能性が考えられる。一方後者は, 堆積物間隙 水あるいは油田咸水と類似した性質を持つ, 地 層中に封入された塩水を起源としている可能性 が考えられた。また，前者の温泉の塩化物イオ ンについては, 地層中に封入された塩水が地下 水により様々な割合に希釈された可能性を考慮 する必要があると考えられた。

今後は, 陽イオンデータも用いた水質形成機構 の考察を行っていきたいと考えている。

\section{謝 辞}

温泉水試料·試料の収集, 水温, $\mathrm{pH}$, および電 気伝導度の測定は笠井加一郎氏をはじめとする地 熱エンジニアリング(侏)の方々により, 水の水素 · 酸素同位体比分析は上田 晃氏・川端明子氏をは ビめとする三菱マテリアル(侏総合研究所の方々に より, 重炭酸イオン濃度の測定は筑波大学大学院 の李盛源, Khan Md Hasmatullah 両氏によりそれ ぞれ行われた。2名の査読者の方々からは論文の 不備についての重要なご指摘をいただいた。ここ に記して深甚なる謝意を表します。

\section{参考文献}

福島県厚生部（1978）: 福島県の温泉（昭和 53 年 
版). 65p.

稲村明彦·安原正也（2003）: 関東平野と周辺山地 の河川水の水素 - 酸素同位体比. 日本水文科学 会誌, 33, 115-124.

いわき市史編さん委員会（1975）：いわき市史·第 二巻 近世, いわき市, $872 \mathrm{p}$.

加藤 進・梶原義照 (1986)：新潟地域油・ガス田 付随水の水素および酸素の同位体組成. 石油技 術協会誌, 51, 113-122.

加藤 進·安田善雄 - 西田英毅 (2000)：秋田·山 形地域油・ガス田の地層水の地球化学. 石油技 術協会誌, 65, 229-237.

角 清愛（1977）：日本に打ける温泉放熱量分布 と地質構造区の関係．地質調査所月報， 28 , 277-325.

高橋正明（1997）: 深部地熱系にはどんな水があ るのか一熱水系の熱的·化学的分類について一. 日本水文科学会誌, 27, 95-103. 地質調查所（1914）：常磐炭田第一区磐城国石城 郡湯本村附近地質図および同説明書, 46p. 地質調查所（1980）: 日本温泉放熱量分布図. 1: 2,000,000 地質編集図.

中村新太郎 (1909)：福島県石城郡湯本温泉調查報 文. 地質調查所報告, no.14, 35-56. 中村久由.安藤 武 (1953): 常磐炭田坑内温泉 水について. 地質調査所月報, 4, 355-382. 中村久由 (1962)：本邦諸温泉の地質学的研究. 地 質調查所報告, no.192, 126p.

日本の地質「東北地方」編集委員会 (1989)：日本 の地質 2 東北地方, 共立出版, 東京, 338p. NEDO : 新エネルギー・産業技術総合開発機構 （1991）: 平成 2 年度全国地熱資源総合調查（第 3 次）広域熱水流動系調査 磐梯地域 地熱調 查成果図集, $88 \mathrm{p}$.

比留川 貴（1981）: 日本の主要地熱地域の熱水 の化学組成, その 2. 地質調査所報告, no. 262 , 403p.

福富孝治（1965）：地下水起源の温泉の温度. 北 海道大学地球物理学研究報告, no. 13, 53-70. 松葉谷 治 (1981)：水素および酸素同位体比か
らみた温泉水の起源. 温泉科学, 31, 47-56. 早稲田 周-中井信之 (1983)：中部日本·東北日 本に打ける天然水の同位体組成. 地球化学, 17, 83-91.

渡部直喜·大木靖衛·佐藤 修·日下部 実(1996)： 新潟県松之山地すべり地の $\mathrm{Na}-\mathrm{Cl}$ 型地下水の起 源. 新潟大学積雪地域災害研究センター研究年 報, no.18, 81-92.

Fukutomi, T. (1961): Rates of discharge of heat energy from the principal hot spring localities in Hokkaido, Japan. Journal of the Faculty of Science Hokkaido University ser VII Geohysics, 1, 315-330. Jenden, P. D. and Gieskes, J. M. (1984): Chemical and isotopic composition of interstitial water from deep sea drilling project sites 533 and 534. Initial Report, DSDP, 76, 453-461.

Matsubaya, O., Sakai, H., Kusachi, I. and Sakai, H. (1973): Hydrogen and oxygen isotopic ratios and major element chemistry of Japanese thermal water systems. Geochemical Journal, 7, 123-151.

Mizota, C. and Kusakabe, M. (1994): Spatial distribution of $\delta \mathrm{D}-\delta{ }^{18} \mathrm{O}$ values of surface and shallow groundwaters from Japan, south Korea and east China. Geochemical Journal, 28, 387-410.

Mizukami, M., Sakai, H. and Matsubaya, O. (1977): $\mathrm{Na}-\mathrm{Ca}-\mathrm{Cl}-\mathrm{SO}_{4}$ type submarine formation waters at the Seikan undersea tunnel, Japan. Chemical and isotopic documentation and its interpretation. Geochimica et Cosmochimica Acta, 41, 1201-1212.

Sakai, H. and Matsubaya, O. (1974): Isotopic geochemistry of the thermal waters of Japan and its bearing on the Kuroko Ore solutions. Economic Geology, 69, 974-991.

（受付 2004年 3 月29日)

（受理 2004年10月 7 日）

この論文に対する「討論」を2004年 5 月31日ま で受け付けます。 